\title{
The determinants and consequences of finance committee use
}

\begin{abstract}
Finance committees are the most commonly created voluntary committees of boards. Finance committees oversee and advise management on financial issues. We study why firms create finance committees and whether firms benefit from using a finance committee. We predict that firms that need finance expertise would benefit the most from having a finance committee, and thus, are more likely to form such a committee. We find that firms are more likely to have a finance committee when they have derivatives, defined benefit pension plans, high leverage and credit ratings, and active dividend payout. We examine the impact of finance committees on investment performance using two proxies, investment efficiency and capital expenditure (capex) guidance quality. We find that firms with a temporary finance committee invest more efficiently and provide capex guidance more frequently. We find no association between finance committee use and capex forecast issuance, accuracy and precision.
\end{abstract}




\section{Introduction}

We study the determinants and consequences of firms' use of finance committees of their directors. Corporate directors conduct many governance responsibilities in their firm's committees and subcommittees rather than involving the full board. Since 2003, U.S. public companies are required to have audit, compensation and nominating/governance committees, each composed entirely of independent directors. Many firms voluntarily create other committees, presumably estimating their net benefits to be positive. Since the most common voluntary committee is a finance committee, we study why and when firms create them.

Many influential firms have instituted finance committees, suggesting that this is an important emerging governance mechanism. General Electric (GE) established a Finance \& Capital Allocation Committee in December 2017 to oversee significant M\&A activity and other capital allocation decisions, such as investments, buybacks, and dividends (GE 2018). Some of the new finance committee's duties were previously handled by the full board as we illustrate in Appendix A. ${ }^{1}$ Pozen (2018) attributes GE's recent pension deficit and cash flow drain at least partially to its late adoption of a finance committee. ${ }^{2}$ Since firms likely vary in the financial issues that would benefit from the monitoring and advice of a dedicated committee, we think it is important to document the issues that appear to matter most.

We sample the proxy statements of firms that have a finance committee to understand their goals and composition. Finance committees engage in mostly finance-related matters and are mainly composed of financial experts. Commonly cited responsibilities include investment policies, financing decisions, payout policy, capital structure, and risk management. Many firms call it a "Finance Committee" although other common names include "Investment Committee," "Risk Management Committee," and "Merger and Acquisitions Committee." In our main sample of over thirty thousand unregulated U.S.

\footnotetext{
${ }^{1}$ GE's Finance and Capital Allocation Committee will be dissolved as the board has decided to dissolve the committee and to reallocate its responsibilities to the full board and audit committee (GE 2019).

${ }^{2}$ Pozen (2018) published on July 17, 2018 after GE adopted the finance committee in December 2017. He argues that GE "had struggled to cope with the cash flow drain from years of problematic acquisitions, divestitures, and buybacks" because "the structure and processes of the GE board were poorly designed for effectively overseeing Immelt and his management team." One of the problems he points out is that the board had no finance committee. In addition, he also argues that the board was too big and the board's audit committee wasn't paying attention.
} 
public firms from 2003 to $2017,13 \%$ have a finance committee. This proportion accounts for about $40 \%$ of the sample market value, indicating that finance committees are especially popular in large companies. Many firms retain their finance committee as a standing committee, but others dissolve the finance committee after a few years.

We first examine why firms have a finance committee. Proxy statements suggest that finance committees are created deliberately (e.g., to address specific issues). ${ }^{3}$ For instance, Verizon created a finance committee to increase oversight of the company's cash flows and liquidity because the company was going to incur significant additional debt to complete an acquisition (Appendix B). If finance committees exist to increase oversight and better advise on financial issues, we expect that firms with problematic financial-matters are most likely to adopt them. Specifically, we argue that complex firms with intense finance-related work are more likely to have a finance committee. Motivated by reading hundreds of proxy statements of firms with a finance committee, we examine financial complexity, debt financing, payout policy, and investment activity as potential determinants of having a finance committee.

In our sample, firms are more likely to have a finance committee when they have derivatives, defined benefit pension plans, high leverage and credit rating, and active dividend payout. This is consistent with our prediction that firms that need financial expertise are more likely to have a finance committee. Furthermore, we find that a CEO's MBA degree, board size and independence as well as firm size and age are positively associated with the existence of a finance committee. We also investigate whether the determinants are different for standing committees and temporary committees and find that investments (i.e., $R \& D$ expenses) affect permanency of a finance committee.

Next, we investigate whether companies benefit from having a finance committee. If creating a finance committee makes directors more effective, we expect finance committees to improve firm performance on average. Prior studies document a positive association between the financial expertise of

\footnotetext{
${ }^{3}$ Many firms, but not all, list their reasons why they create a finance committee. For example, Verizon adopted a finance committee in November 2013 and explained why in its next proxy statement (Version 2014): "Because the Company was going to incur significant additional debt in order to complete this acquisition, the Board determined that it should increase its oversight of the Company's cash flows and liquidity through the creation of a Finance Committee of Directors with significant financial expertise."
} 
audit committees and financial reporting quality (Xie, Davidson, and DaDalt 2003; Bedard, Chtourou, and Courteau 2004; Krishnan and Visvanathan 2008; Badolato, Donelson, and Ege 2014). Similarly, bringing together a group of financial experts in a finance committee to guide management should ultimately improve financial performance. However, boards without such committees might monitor and advise management on financial matters at the board level or through other mandatory committees, such as an audit committee. ${ }^{4}$ Firms might also form a finance committee to imitate influential companies rather than with a specific purpose. Therefore, it is an empirical question whether a finance committee improves financial performance.

We examine the impact of finance committees on investment performance because the main responsibilities of finance committees are often related to investment policies and capital allocation. Specifically, we examine the impact of having a finance committee on investment efficiency and the quality of capital expenditure (capex) guidance. We find that firms with a temporary finance committee deviate less from the expected investment level, which indicates higher investment efficiency. Second, we examine whether firms with a finance committee have better capex guidance. We use four proxies for the quality of capex guidance--likelihood, frequency, accuracy, and precision--and find mixed evidence. We find a positive association between the use of temporary finance committees and frequency of capex forecasts. The remaining three proxies are not significantly associated with finance committee use. Given the mixed evidence, we infer that finance committees improve investment decisions but not by much.

To our knowledge, this is the first paper to study finance committees as an independent topic. We expect this study to advance our understanding of boards by examining a new way that boards improve their efficiency. Considering that the finance committee is voluntarily created by firms, the active use of finance committees suggests that boards are not simply a static governance form. Rather, we provide evidence that boards evolve to respond to new environments and to perform their monitoring and advisory roles. The limited evidence of positive impacts of the finance committee suggests that having a

\footnotetext{
${ }^{4}$ Some firms name the audit committee as 'audit and finance committee' and include oversight of finance related issues as the main responsibilities, suggesting that boards self-organize their functioning endogenously in different ways.
} 
separate committee for finance matters is not always ideal. Boards at some firms can provide enough advice without delegating their jobs to a specific committee.

Section 2 provides background information. Section 3 develops hypotheses. Section 4 describes the data. Sections 5 and 6 present research design and empirical results for the determinants and consequences of the finance committee, respectively. Section 7 provides additional analyses and section 8 concludes.

\section{Background information}

\subsection{Literature review on board committees}

Board committees have long been used. Since 1940, the U.S. Securities and Exchange Commission (SEC) has recommended that firms establish an audit committee comprised of independent directors. Since 1978, The New York Stock Exchange (NYSE) has required all listed firms to have an audit committee (Birkett 1986). Starting in 2003, when the Sarbanes-Oxley Act (SOX) was passed, the major stock exchanges mandated that firms have compensation and governance committees in addition to an audit committee. Thus, since 2003, US public companies have been required to have three board committees: audit, compensation, and governance. Even before the mandatory regime, 32 and 87 percent of US companies already had audit committees in 1970, and 1976, respectively (Mautz and Neuman 1977). NASDAQ firms also voluntarily formed audit committees when they were not required (Pincus, Rusbarsky, and Wong 1989). The long history of regulations pushing for such committees, along with companies' active use of them, suggests the usefulness and benefits of having committees under boards.

Committees have pros and cons for firms. Compared to boards, committees are smaller and have more specific responsibilities (Klein 1998). Reeb and Upadhyay (2001) argue that committees reduce the communication challenges and lack of participation often found on boards, especially large ones. They find that in firms with large boards, having multiple committees under the board can offset the negative associations between board size and firm performance. Chen and $\mathrm{Wu}$ (2016) examine benefits and costs of committees. They argue that benefits include knowledge specialization and increased accountability of 
the board through efficient task allocation, and costs include information segregation. Committee usage could have other costs as well; for instance, having multiple committees comes with financial expense to the firms because the board needs to support the committees' activities and compensate the directors who sit on those committees.

Committees are becoming increasingly common. Adams, Ragunathan, and Rumarkin (2017) document a dramatic increase in the total number of committee meetings per year after SOX. Chen and $\mathrm{Wu}$ (2016) report the frequencies of specified committees in U.S. public firms from 2001 to 2013. The most frequently used committees after the three required ones are executive, finance, and strategy, and 12 percent of the sample uses a finance committee. ${ }^{5}$ Other voluntary committees include environment, health, safety, technology, public policy, pension, M\&A, litigation, diversity, and loan. The diversity of committees and specificity of their names suggest that firms use different committees for different needs.

\subsection{Introducing finance committees}

In this section, we describe how we identify finance committees, introduce different types of finance committees, and show a distribution of finance committees by industry and year. To identify whether each firm has a finance committee, we downloaded a complete list of committees in BoardEx and develop a keyword list to define a finance committee. The keywords include "finance," "invest," “acquisition," "M\&A," “merger," "asset," "budget," “capital," “credit," "risk," "loan,” and "pension.” We coded the variable Finance Committee as 1 if a firm has a committee whose name includes one or more of the keywords.

Some firms retain finance committees permanently while others dissolve the committee a few years after their adoption. As incentives and functions might vary with committee permanence, we partition finance committees into permanent if the committee lasts for over 80 percent of the period since

\footnotetext{
${ }^{5}$ The most frequently used committee after the three required ones in Chen and $\mathrm{Wu}(2016)$ is executive committee. Chen and $\mathrm{Wu}$ (2016) explain that executive committee is composed of the chair, the CEO, officers, and a few outside directors to act on behalf of the board when the full board cannot meet. Given that the executive committee is operating party of the boards, we argue that finance committees are the most frequently used voluntary committee throughout this paper.
} 
it was created to the end of sample period, and temporary otherwise. ${ }^{6}$ In our sample, the average duration of a finance committee is about ten years, and 90 percent of the remaining period.

Figure 1 breaks down the use of finance committees by industry. About fifteen (two) percent of firms have a permanent (temporary) finance committee, and the remaining 83 percent do not have a finance committee. We find a higher proportion of firms with a finance committee in the utilities and financial industries, 45 percent and 26 percent, respectively. Permanent committees are much more common than temporary committees in all industries.

Figure 2 shows ten most common titles of finance committees along with proportion of each title keyword by year for regulated and unregulated industries separately. We use Fama-French 12 industry classification. Regulated industries include the utilities and financial industries. In unregulated industries, the most common title is "finance committee" followed by "investments committee." In regulated industries, the keyword "risk" became more dominant than "financ" since 2011, likely because the Federal Reserve Board of Governors has required certain bank holding companies to establish a risk committee since $2015 .^{7}$ The differing titles of finance committees between the two groups suggests that risk management might be the top priority for regulated industries whereas finance and investment decisions might be the focal issues for unregulated industries.

Panels A and B of Figure 3 show the frequencies of finance committees by year for unregulated and regulated industries, respectively. We display both equal-weighted and market-value-weighted proportions of firms with a finance committee. In Panel A, on average about $13 \%$ of unregulated firms use a finance committee every year. ${ }^{8}$ Firms with a finance committee account for about 40 percent of the

\footnotetext{
${ }^{6}$ This ex-post measure uses observed duration to define permanence. Because firms rarely label a committee as ad hoc even if they intend it to be temporary, we do not have a good ex-ante basis to partition finance committees.

${ }^{7}$ On February 18, 2014, the Federal Reserve Board of Governors adopted rules implementing risk committee requirements for certain entities including: publicly traded nonbank financial companies supervised by the Federal Reserve Board of Governors, publicly traded bank holding companies with total consolidated assets of $\$ 10$ billion or more, and publicly traded bank holding companies with total consolidated assets of less than $\$ 10$ billion where Federal Reserve Board of Governors has determined that establishment of risk committee is necessary.

(https://www.federalreserve.gov/reportforms/formsreview/RegYY_20120105_ifr.pdf)

${ }^{8}$ On average, 43 firms create a finance committee every year (untabulated). We find more adopters in the earlier years, but there are new adopters every year through 2017.
} 
unregulated sample market value, indicating that large firms disproportionately use finance committees. In both graphs, permanent (temporary) finance committees are becoming more (less) common. Finance committee frequencies in regulated industries are presented in Panel B. About 25 percent of regulated firms had a finance committee in the early 2000s and this proportion grew until recently. Over 50 percent of regulated firms by market value had a finance committee in 2003 and the proportion increased to 67 percent in 2017. Since we are interested in the voluntary adoption of finance committees, we exclude regulated industries in our subsequent analyses, and leave the separate study of finance committees in regulated industries to future studies.

\section{Hypotheses development}

\subsection{The determinants of having a finance committee}

As established above, firms use committees for various reasons. We expect that firms in great need of finance expertise would benefit the most from having a finance committee, and thus, are more likely to form such a committee. Although prior studies have not examined this possibility directly, they document that firms with a strong need for finance or accounting knowledge and skills hire executives withexpertise in those fields (Li, Sun, and Ettredge 2010; Hoitash, Hoitash, and Kurt 2016; Bernard, Ge, Matsumoto and Toynbee 2018). Boone and Mulherin (2017) document that target firms use special committees during corporate takeovers. Similarly, finance committees could also be used to meet these needs, either as an alternative or supplement to hiring executives with the desired expertise.

To understand firms' motivations for forming a finance committee, we examined their proxy statements. We looked at sections where firms describe the purpose, goals, and responsibilities of each committee of the board. By reading a couple hundred proxy statements for thirty companies, we identified four recurring themes, or potential driving factors, to study: financial complexity, debt financing, payout policy, and investment activity. Appendix B quotes proxy statements to motivate each hypothesis. 
In the first hypothesis, we predict that firms with high financial complexity are more likely to have a finance committee. We consider derivative usage, a foreign exchange activity, use of defined benefit (DB) pension plans, and deferred tax as proxies for financial complexity.

Derivatives can be useful for risk management (Guay 1999; Bodnar, Hayt, Marston, and Smithson 1995; Bartram, Brown, and Fehle 2004), but they can also create risk, especially if not properly used (Stulz 2004). The prevalence of derivative use and difficulty of derivative management suggest derivate usage as a determinant of having a finance committee. In this context, we also expect firms with foreign exchange activity to be more likely to have a finance committee because globally-diversified firms often use derivatives to reduce exchange-rate risk exposure (Denies, Denies and Yost 2002; Choi and Jiang 2009).

Pensions account for a significant portion of firms' costs (Sundaram and Yermack 2007). Unlike defined contribution (DC) plans, DB plans impose investment risks of the fund assets on the sponsoring firms. Therefore, firms that have DB plans may benefit from having extra advice from a finance committee.

Tax avoidance is a red flag for earnings management. Phillips (2003) document that deferred tax expense is associated with avoiding losses or meeting analysts' forecasts. If firms that have large deferred tax expenses or that avoid taxes aggressively are more likely to manage earnings, their shareholders should worry about transparency, and thus be more likely to support an extra board committee. We thus expect the degree of tax avoidance to be positively associated with the likelihood of having a finance committee. All of this leads to our first hypothesis:

\section{H1. Firms with high financial complexity are more likely to have a finance committee.}

In the second hypothesis, we examine leverage, credit ratings, and issuance of debt as proxies for reliance on external funding. Firms with high leverage have greater advising requirements (Pfeffer 1971). Experts such as bankers on boards help firms to access external funds (Booth and Deli 1999; Güner, Malmendier, and Tate 2008). We argue that finance committees can provide similar advice (if not more), and thus, firms seeking external funds would benefit from having such a committee. Similarly, firms that 
need external funds or that are currently using debt have incentives to manage their credit ratings. We expect finance committees to provide helpful advice on credit rating management and thus predict an association between credit ratings and having a finance committee. This leads to our second hypothesis: H2. Firms with high reliance on external funds are more likely to have a finance committee.

Payout policy is yet another critical decision of firms. Good governance can be particularly important in payout policy because dividend payout involves agency conflicts (Jensen 1986). Shareholders would institute a finance committee to ensure that managers do not adopt a suboptimal dividend policy. As more firms mix dividends and share repurchases (DeAngelo, DeAngelo, and Skinner 2008; Skinner 2008; Kahle and Stulz 2017), managers also need to choose the payout form. Based on the importance and difficulty of managing payout, we argue that firms with active payout need more advice from specialists and, thus, are more likely to use a finance committee. This leads to our third hypothesis: H3. Firms with active payout policy are more likely to have a finance committee.

Investment is arguably the most highly related to finance committee's agenda. Not only responsibilities of the finance committee almost always include investment related duties but also many firms use an "Investment Committee" label. Investment activities of firms are directly related to the firm's profitability and growth. Managers in a firm with active investments would need advice from experts to find good investment projects and to manage current investments. Therefore, we expect to see a higher likelihood of having a finance committee for the firms with active investment such as capex, R\&D and M\&A. This leads to our fourth hypothesis:

H4. Firms with active investments are more likely to have a finance committee.

\subsection{The consequences of using a finance committee}

Finance committees are responsible for monitoring and advising the firm's investment decisions, which we use as our main performance proxy. Prior studies document that good governance improves firms' decision-making. Much accounting research has examined the quality of audit committees and its impact on accounting and audit performance (Xie, et al., 2003; Bedard et al., 2004; Krishnan 2005; 
Krishnan and Visvanathan 2008; Dhaliwal, Naiker, and Navissi 2010). Basu and Liang (2018) provide causal evidence that outside directors (not just audit committee members) affect conservatism. Whereas the main goal of audit committees is to ensure financial reporting quality, finance committees mainly oversee and assess finance outcomes. To the extent that a finance committee can help directors be more effective in guiding management to high-quality financial decisions, having a finance committee in place should lead to better investment decisions made by the firm.

Researchers have looked at how the financial literacy of boards affects firm performance. Güner et al. (2008) document that external funding increases and investment-cash flow sensitivity decreases when commercial bankers join boards. Mangena and Pike (2005) document a significant positive association between audit committee financial expertise and interim disclosure. SOX required employment and disclosure of financial experts on audit committees to enhance effective financial oversight. The reasoning is that directors who possess the skills and experience relevant to the tasks at hand will ask more challenging questions and provide better advice to management. By the same logic, a finance committee should increase investment quality because it is essentially a group of financial experts who meet regularly to oversee and advise the management regarding financial issues, including investment decisions.

Several accounting studies differentiate accounting from nonaccounting financial expertise and compare the impacts of both. Krishnan and Visvanathan (2009) document that audit fees are lower for firms with accounting financial expertise on their audit committees but not for firms with nonaccounting financial expertise. Similarly, DeFond, Hann, and $\mathrm{Hu}$ (2005) find a positive market reaction to appointing accounting financial experts to audit committees but no reaction to appointing nonaccounting financial experts. These studies suggest that nonaccounting financial expertise on audit committees might not have a strong impact on audit performance. Arguably, accounting financial expertise (e.g., CPA, controller), as opposed to nonaccounting financial expertise (e.g., banking, treasurer), should be more related to accounting performance (e.g., financial reporting quality) than to financial performance (e.g., investment 
outcomes). On the contrary, we predict that finance committees have stronger impact on financial performance such as investment performance than on accounting performance.

To examine consequences of finance committees, we analyze two investment related variables: investment efficiency and capex guidance. First, we examine whether firms with a finance committee invest more efficiently than those without a committee. Prior studies document that a firm's financial reporting choices and information environment influence its investment efficiency (Biddle, Hilary and Verdi 2009; Chen, Hope, Li and Wang 2011; Goodman, Neamtiu, Shroff, and White 2013; Choi, Hann and Subasi 2018). Biddle et al. (2009) find that firms with higher financial reporting quality deviate less from predicted investment levels. Francis and Martin (2010) document that timely loss recognition is positively associated with acquisition profitability. Goodman et al. (2013) document that investment efficiency is positively associated with management forecasting quality. In addition to these findings, we conjecture that the finance committee is another factor that can impact a firm's investment efficiency. Specifically, if directing members of the finance committee work closely with management in discussing investment opportunities and funding options, management should better estimate the value of potential investment projects and, accordingly, invest more efficiently. All of this leads to our next hypothesis: H5. Firms with a finance committee have higher investment efficiency.

Second, we examine whether firms with a finance committee provide better capex guidance. Management reports the firm's spending and budgeting plan to the finance committee and seek feedback. In such firms, management should have a better idea about future investment plans and be more capable of forecasting investment amounts. A better understanding and forecasting of investment projects' future payoffs would help managers provide high-quality capex guidance. To measure capex guidance quality, we examine the likelihood of providing capex forecasts, frequency of forecast updates, and accuracy and precision of the forecasts. Although management forecasts on other items (e.g., earnings forecast) might also be related to having a finance committee, we choose capex guidance because it is more directly linked to firm's investment decisions. This leads to our next hypothesis:

H6. Firms with a finance committee provide better capex guidance. 
For some firms, forming a finance committee might not be necessary. That is, some firms might be handling their financial decisions well without a finance committee. Given that investment drives value creation (Modigliani and Miller 1958) and boards themselves respond to their environments (Hermalin and Weisbach 2001), it is very likely that boards are monitoring and advising investment decisions regardless of whether a finance committee is in place. This might be especially true for firms that employ many financial experts because then the directors can easily discuss financial matters at board meetings. Some firms refer to their audit committee as the "Audit and Finance Committee," indicating that the audit committee is also involved in finance-related matters. Lastly, it is also possible that firms create a finance committee to imitate successful firms rather than for any specific function. If any of these cases are true, we would not find a positive impact of having a finance committee.

\section{Sample selection and data description}

\subsection{Sample selection}

We collect data from 2003 to 2017. We start our sample in 2003 for two reasons. First, the Sarbanes-Oxley Act of 2002 (SOX) introduced many changes in governance including mandating certain board committees and their composition, so we restrict ourselves to a post-SOX sample. Second, BoardEx, our main data source for boards and committees, has incomplete coverage before 2002.

Panel A of Table 1 presents our sample selection procedure. We start with 82,775 firm-year observations that have complete data about committees in BoardEx. After excluding observations without CIK codes or SIC industry codes, we have 65,571 observations in the combined BoardEx/Compustat sample. We dropped utilities and financial firms because of possible regulations regarding board committees. After further attrition due to missing financial data, we have 37,902 firm-year observations for analyses of finance committee determinants. Sample size is smaller for our consequences tests because of data unavailability to construct required variables for each analysis. 
Accounting and other financial data, including pension data and S\&P credit ratings, are taken from Compustat. Institutional ownership data are taken from Thomson Reuters $13 \mathrm{f}$ filings. Analyst forecasts and management guidance data are from the $\mathrm{I} / \mathrm{B} / \mathrm{E} / \mathrm{S}$ Detail file.

\subsection{Summary statistics about finance committees}

Panels B and C of Table 1 present descriptive statistics on finance committees. We explore the accounting and/or finance expertise of boards and committees based on three kinds of experts - finance expert, accounting expert, and supervisory expert. Following prior literature (DeFond et al. 2005;

Krishnan and Visvanathan 2008; Badolato et al. 2014), we search for certain keywords in education, qualification, and prior employment history of directors on BoardEx. To identify accounting experts, we use the following keywords: "CPA," “accounting," "accountant," “accountancy," "audit," "controller," "internal control," "financial report," and "CFO." For finance experts, we use the following keywords: "finance," "analyst," "invest," “asset," "capital," “credit," "fund," "loan," "budget," "bank," "treasur." Our definitions of finance experts and accounting experts are narrower than the SEC's definition of financial experts, which include directors who experience supervising and overseeing financial or accounting officer. ${ }^{9}$ We thus include supervisory expert which is coded 1 for the director with supervisory expertise using keywords of "CEO" and "president." Expert is coded 1 if any of the three expertise variables is coded 1 . .

In panel B, we examine how board composition changes when firms first adopt a finance committee. We use non-adopting years (both before and after adoption) for the same firms as a benchmark. In adopting years, board size increases about three percent from the previous year, which is more than in non-adopting years. We also observe an increase in the number of both accounting and

\footnotetext{
${ }^{9}$ The SEC defines "financial expert" broadly to include individuals with any experience creating, auditing, using or overseeing the creation of financial reports (SEC 2003). The SEC does not list job titles that qualify directors as financial experts, but those qualifying include auditors, presidents, CEOs, and CFOs (Krishnan and Visvanathan 1998; DeFond et al. 2005).
} 
finance experts in adopting years. In short, at least some boards hire new directors, especially accounting and/or finance experts when they create a finance committee.

Panel $\mathrm{C}$ of Table 1 compares the size and composition of finance committees to those of three required committees in the same firms. On average, a finance committee has 4.6 directors, which is slightly more than of the other committees. 27 percent of finance committee members have accounting expertise and 25 percent have finance expertise. Using the broader SEC-style definition which includes supervisory experts as well as finance and accounting experts, 89 percent of finance committee members are financial experts. Audit committees have more accounting and finance experts on average than finance committees, which partially reflects the requirement that audit committees have at least one financial expert (SEC 2003). Finance committees have more accounting and finance experts than compensation and nominating/governance committees. The last three rows of the table show what proportion of the financial experts on a board are allocated to each committee. Boards allocate about 60 percent of their finance experts to the finance committee. Overall, Panels B and C provide suggestive evidence that a finance committee is mainly consist of financial experts who have accounting and/or finance background.

\section{Determinants of finance committee use}

\subsection{Empirical model}

We test four hypotheses on the determinants of having a finance committee using a logit regression:

$$
\begin{aligned}
& \operatorname{Pr}(\text { Finanace Committee }=1) \\
& =\operatorname{Logit}\left(\alpha+\sum \beta_{i} \text { Financial Complexity }+\sum \gamma_{j} \text { Debt Financing }+\sum \delta_{k}\right. \text { Payout } \\
& +\sum \theta_{l} \text { Investment }+ \text { Controls }+ \text { YearFE }+ \text { Industry FE) }
\end{aligned}
$$

where Finance Committee is an indicator variable that takes a value of one (zero) if a firm has (does not have) a finance committee. Financial Complexity, Debt Financing, Payout, and Investment label the four sets of proxies to test $\mathrm{H} 1$ to $\mathrm{H} 4$. 
To test H1, which is that financially complex firms are more likely to have a finance committee, we use indicator variables for use of derivatives (Derivative User), existence of foreign operations (Foreign), use of defined benefit plans (DBplan User) and level of deferred tax expenses (Deferred $\operatorname{Tax}){ }^{10}$

To test $\mathrm{H} 2$, which is that firms that seek external funds are more likely to have a finance committee, we examine the ratio of total debt to equity (Leverage), credit ratings from Standard \& Poor's (Ratings) and net debt financing (Debt Financing). The ratings range from AAA (highest rating) to D (lowest rating). Following Ashbaugh-Skaife, Collins, and LaFond (2006), we collapsed multiple ratings into seven categories with seven being the highest and one being the lowest. We assign zero to observations with no ratings. We add an indicator variable for observations with missing ratings (Missing Ratings) to account for variability in finance committee use by existence of credit ratings.

To test $\mathrm{H} 3$, which is that firms paying out cash are more likely to have a finance committee, we include indicator variables for dividend-paying firms (DivPayer) and firms with positive net repurchases (Repurchase).

To test H4, which is that firms with active investments are more likely to have a finance committee, we include different investments including capital expenditure (CAPEX) and research and development $(R \& D)$, indicator variables for having acquisition (Acquisition), divestiture (Divestiture), and restructure (Restructure). ${ }^{11}$

We control for board characteristics—-board size (Baord Size) and independence (Board Independence) - that are known to affect committee use (Reeb and Upadhyay 2010; Chen and Wu 2016). We include institutional ownership (InstOwn) as an external governance proxy. Finally, we include firm size proxied by $\log$ of market value of equity ( $\log M V E$ ), firm age (Firm Age) and profitability $(R O A)$, risk proxied by standard deviation of market returns (Ret Volatility). We include industry and year

\footnotetext{
${ }^{10}$ Detailed amounts and status of derivatives and pension assets are only available through manual collection from 10-Ks. We thus create indicator variables using data items available on Compustat following prior research (Franzoni and Marin 2006; Campbell 2015).

${ }^{11}$ Divestitures are not available in Compustat. We instead use discontinued operations (Compustat item DO) to proxy for existence of divestitures following Hribar and Collins (2002).
} 
fixed effects. Standard errors are clustered at the firm level. Appendix C lists all variables and their definitions. All continuous variables are winsorized at the $1^{\text {st }}$ and $99^{\text {th }}$ percentile to limit the influence of any outliers.

We define the variables so that their predicted signs are positive. While not a formal hypothesis, we also explore whether top executives' background is related to the likelihood of having a finance committee. Top executives' backgrounds and styles affect various firm decisions (Bertrand and Schoar 2003; Bamber, Jian, and Wang 2010; Ge, Matsumoto, and Zhang 2011; Graham, Harvey, and Puri 2013). Therefore, we investigate whether CEOs and CFOs influence this voluntary choice. Specifically, we include indicator variables for CEOs and CFOs with an MBA degree (CEO with MBA, CFO with MBA), accounting expertise (Accounting Expert CEO, Accounting Expert CFO), and finance expertise (Finance Expert CEO, Finance Expert $C F O)$.

\subsection{Empirical results}

\subsubsection{Descriptive statistics}

In Table 2, we compare potential determinants across three groups of firms: firms without a finance committee, firms with a temporary finance committee, and firms with a permanent finance committee. Columns (1) through (3) present the average values of each variable for each group and columns (4) through (6) show paired sample t-statistics comparing each pair among the three groups.

Under H1, financially complex firms are expected to use finance committees. First, compared to firms with no finance committee, firms with a permanent finance committee have more complex financial transactions. The usage of derivatives and defined benefit plans is higher for firms with a finance committee. Even among firms that have a finance committee, firms with a permanent committee use derivatives and defined benefit plans much more. Overall, the results are consistent with H1.

In $\mathrm{H} 2$, we expect external financing to influence having a finance committee. Firms with a permanent finance committee have the highest leverage and the highest credit rating, which are 
significantly higher than the other two groups. We find no significant differences in the level of new debt financing among the three groups.

$\mathrm{H} 3$ predicts active payout policy to influence finance committee use. Consistent with $\mathrm{H} 3$, the proportions of dividend payout and repurchase increase from firms with no finance committee to firms with a temporary committee to firms with a permanent committee.

Lastly, in $\mathrm{H} 4$, we consider active investments to influence having a finance committee. We find no significant differences in capex across the three groups. Firms without a finance committee appear to spend the most on R\&D. We find higher frequencies of acquisitions, divestitures, and restructurings in firms that have a finance committee, either permanent or temporary, than in firms without a finance committee.

We find a monotonic increase in board size and independence from no committee to temporary to permanent committee. Firms with large, independent boards are more likely to have a finance committee. The average values of firm size, ROA, age and institutional ownership are the highest for the group of firms with a permanent finance committee followed by firms with a temporary committee then by firms without a finance committee. Volatility has the opposite order, no finance committee being the highest and permanent committee being the lowest, suggesting that risker firms are less likely to have a finance committee contrary to our prediction.

In addition, we compare CEOs' and CFOs' background across the three groups. ${ }^{12}$ For both CEOs and CFOs, firms with a finance committee have a higher percentage of CEOs with an MBA degree than firms without a finance committee. In general, CEOs and CFOs in firms without a finance committee have more accounting expertise while those in firms with a permanent finance committee have more finance expertise.

\subsubsection{Tests of finance committee determinants}

\footnotetext{
12 The sample size drops significantly when CEOs' and CFOs' background is considered because BoardEx does not have data for many executives.
} 
Table 3 presents the results of estimating equation (1). Panel A shows a binary logit model and Panel B shows a multinomial logit model. The first four columns in Panel A show the basic model where we do not distinguish permanent committees from temporary committees.

Columns (1) and (2) show the coefficients and marginal effects of each determinant. Use of derivatives and defined benefit pension plans, credit ratings, and dividend payment are reliably associated with having a finance committee. Firms that use derivatives (defined benefit plans) are 1.3 (2.9) percent more likely to have a finance committee than their counterparts. Also, firms with credit ratings are 5.2 percent more likely to have a finance committee. Dividend payers are 2.2 percent more likely to have a finance committee. These results are consistent with our predictions that firms with complex financial transactions $(\mathrm{H} 1)$, high reliance on debt financing $(\mathrm{H} 2)$, and active payout $(\mathrm{H} 3)$ are more likely to use a finance committee. However, we do not find empirical evidence that investments impact firms' decision on having a finance committee (H4).

We find that firms with a larger board and a more independent board, larger firms, and more mature firms are more likely to have a finance committee. Columns (3) and (4) add CEOs' and CFOs' backgrounds to the regression. We find similar results for the determinants and controls. The coefficients on $C E O$ with $M B A$ and Accounting Expert $C E O$ are statistically significant. Companies whose CEOs have an MBA degree are 4.5 percent more likely to have a finance committee whereas firms with an accounting expert CEO are 3.2 percent less likely to have a finance committee. It might be that CEOs who have an MBA degree acknowledge difficulty and importance of finance related issues and thus are more inclined to institute a separate committee to deal with financial issues.

Columns (5) through (8) of Panel A present logit regression results in a subsample of firms with finance committees. The dependent variable is equal to one (zero) if a firm has a permanent (temporary) finance committee. This analysis examines the determinants of a permanent committee over a temporary committee, conditional on the choice to have a finance committee.

Financial complexity $(\mathrm{H} 1)$, debt financing $(\mathrm{H} 2)$, and payout $(\mathrm{H} 3)$ do not explain having a permanent committee instead of a temporary committee (with exceptions of defined benefit plans and 
leverage still showing significantly positive marginal impact in one of the two models). In contrast, $R \& D$ expenses are now statistically significant. This suggests that investment decisions are more related to the types of finance committee rather than existence of the committee. Less profitable firms and firms with higher institutional ownership are more likely to have a permanent committee. In addition to CEO's MBA degree and accounting expertise, CFO's financial expertise is also an important factor for having a permanent committee. Firms with a finance expert CFO are 4.4 percent more likely to have a permanent committee.

In addition to binary logit models, we also use multinomial logit regression, which lets us to consider cases where companies choose directly between no finance committee, a permanent finance committee, and a temporary finance committee. In the previous binary models, we assumed two-stage decision making (i.e., firms first decide whether to have a finance committee, and then choose between permanent and temporary). The results are shown in Panel B. Columns (1) and (3) compare temporary committees to firms with no finance committees while columns (2) and (4) compare permanent committees to the same base group.

When temporary committees are compared to the base group, almost none of the main determinants (H1-H4) is significant. Only the coefficients on Missing Ratings, Acquisition and DivPayer are significantly positive in one of the two models. When permanent committees are compared to the base group of no committees, we find similar results from the binary logit model. DBPlan User, Leverage, Missing Ratings, and DivPayer have significant coefficients with the predicted signs, supporting our first three hypotheses on finance committee determinants. ${ }^{13}$

\section{Consequences of finance committee use}

\footnotetext{
${ }^{13}$ Across all models, the coefficient on Foreign consistently shows a negative sign, suggesting that firms with no foreign operations are less likely to have a finance committee. This is inconsistent with our prediction that firms with foreign operations, which are more complex firms, are more likely to have a finance committee.
} 
As shown in the determinant analysis, firms that have a finance committee differ from those that do not. We used the estimated coefficients from our determinants model to derive propensity scores for using finance committees. ${ }^{14}$ We use these propensity scores to match our samples of firms with and without finance committees, so that we can isolate the incremental effect of a finance committee.

\subsection{Investment efficiency}

\subsubsection{Empirical model}

H5 is that firms with a finance committee will invest more efficiently. We investigate whether having a finance committee reduces firms' deviations from their expected investment levels. Following Biddle et al. (2009), we model investment as a function of growth opportunities (as measured by sales growth). ${ }^{15}$

$$
\text { Investment }_{i, t+1}=\pi_{0}+\pi_{1} * \text { Sales Growth } h_{i, t}+\varepsilon_{i, t+1}
$$

Where Investment $t_{i, t+1}$ is total investment (i.e., sum of R\&D expenditure, capital expenditure, and acquisition expenditure) and Sales Growth ${ }_{i, t}$ is the percentage change in sales from year t-1 to t. Equation (3) is estimated on each industry-year based on Fama and French 48 industries with at least 30 observations in a given industry-year. We use absolute value of the residuals (i.e., deviations from predicted investment) as a continuous measure of investment inefficiency. We also create an indicator that equals one if the absolute residual is above the median because measurement error in this proxy could be high (Erickson and Whited 2006; Goodman et al. 2013). Lastly, we create a change variable that compares the absolute residuals of year $t$ and $t+1$. Using these three measures to proxy for investment inefficiency, we estimate the following Logit (for binary variable) and OLS (for continuous variables) regressions:

\footnotetext{
${ }^{14}$ We perform 1-to-1 matching without replacement using nearest-neighbor (without caliper).

${ }^{15}$ Following Bae, Biddle and Park (2018), we also use an alternative model where investment inefficiency is measured by the absolute value of residuals from a regression of firm's capital expenditures on Tobin's Q and cash flow from operations. The results are qualitatively similar.
} 


$$
\begin{aligned}
& \text { Invest Inefficiency }_{i, t+1} \\
& \qquad \begin{array}{l}
=\rho_{0}+\rho_{1} * \text { Permanent Finance Committe }_{i, t}+\rho_{2} * \text { Temporary Finance Committee }_{i, t} \\
+\tau \text { Control }_{i, t}+\text { IndustryFE }+ \text { YearFE }+\varepsilon_{i, t}
\end{array}
\end{aligned}
$$

Invest Inefficiency $y_{i, t+1}$ is one of the three measures defined above. Permanent Finance Committee ${ }_{i, t}$ is an indicator that equals one if a firm has a permanent finance committee in year t. Temporary Finance Committe $_{i, t}$ is an indicator variable that equals one if a firm has a temporary finance committee in year t. Control $_{i, t}$ is a vector of firm characteristics that might affect investment efficiency. If a finance committee mitigates under- and/or over-investment, $\rho_{1}$ and/or $\rho_{2}$ will be negative.

We follow prior studies (Biddle et al. 2009; Chen et al. 2011; Goodman et al. 2013) to control for the following firm characteristics. We include institutional ownership (InstOwn), analyst following (Analyst Following), and board size (Board Size) because good governance is negatively associated with over- and/or under-investment. We include cash flow volatility (OCF Volatility), sales volatility (Sales Volatility), and investment volatility (Invest Volatility) to control for firm uncertainty. We include controls for basic firm characteristics such as log of total asset (LogAsset), market-to-book ratio (MtoB), firm age (Firm Age), firm's operating cycle (OprCycle), asset tangibility (Tangible), cash flow from operations divided by sales (OCF to Sale), and whether the firm has reported negative earnings (Loss). Since firm liquidity affects investment decisions, we control for capital structure ( $K$-structure $)$ and financial slack (Financial Slack). Lastly, we control for number of committees (NCommittees) to rule out the possibility that results reflect a firm having many committees rather than a finance committee specifically. Appendix C provides detailed variable definitions. We winsorize all continuous variables at the bottom and top $1 \%$ level. Industry and year fixed effects are included, and standard errors are clustered by firm.

\subsubsection{Empirical results}


Since our sample is smaller than before, Panel A of Table 4 lists descriptive statistics for the investment efficiency sample. The firm characteristics of the new sample are similar to that of the earlier sample. In Panel B, we compare investment inefficiency across three groups - firms without a finance committee, firms with a temporary finance committee, and firms with a permanent finance committee. For the investment inefficiency indicator, mild differences are found for overinvestment. For the continuous variable, firms with a permanent committee (temporary committee) seem to have more (less) efficient investment than firms without a finance committee.

Next, we estimate logistic and OLS regressions of investment inefficiency on finance committee. The results of estimating equation (4) are presented in Panel C. Overall, the coefficients on Permanent Finance Committee and Temporary Finance Committee are negative as predicted, but they are in most cases not statistically significant. For the indicator variable, the coefficient on Temporary Finance Committee in column (1) is -0.266 with marginal effects of -0.066 , indicating that firms with a temporary finance committee are 6.6 percent less likely to make an inefficient investment. In column (4), the coefficient is -0.420 with marginal effects of -0.105 . That is, firms with a temporary finance committee are 10.5 percent less likely to involve in underinvestment. Temporary Finance Committee continues to show negative coefficient (-2.255) in column (9) for change variable. In sum, the results of our test of H5 provide some evidence that having a temporary finance committee mitigates inefficient investment, but we cannot draw a clear conclusion given the weak and inconsistent empirical results.

The coefficients on NCommittees are negative in most cases, suggesting that having more committees mitigates investment inefficiency problems. This is consistent with the findings that committee use can reduce costs of large board (Reeb and Upadhyay 2001). Investment inefficiency is negatively correlated with analyst following (Analyst Following) and institutional ownership (InstOwn), suggesting that analysts and institutional investors help mitigate investment inefficiency, consistent with prior studies (Derrien and Kecskés 2013; Chen, Harford, and Lin 2015). The coefficients on the other 
control variables are generally in line with those found in the prior research (Biddle and Hilary 2006;

Biddle et al., 2009; Choi et al. 2018).

\subsection{Quality of capex guidance}

\subsubsection{Empirical model}

H6 is that firms with a finance committee will provide better capex guidance. To study how having a finance committee affects capex guidance quality, we estimate an OLS regression:

\section{Capex Guidance Quality $_{i, t}$}

$$
\begin{aligned}
& =\sigma_{0}+\sigma_{1} \text { Permanent Finance Committe }_{i, t}+\sigma_{2} \text { Temporary Finance Committe }_{i, t} \\
& +\varphi \text { Control }_{i, t}+\text { IndustryFE }+ \text { YearFE }+\varepsilon_{i, t}
\end{aligned}
$$

For the dependent variable, Capex Guidance Quality, we use four different proxies: issuance of capex guidance (Capex Issuance), frequency of capex guidance (NForecast), capex forecast error (Forecast Error), capex forecast range (Forecast Range). Capex Issuance is equal to one if a firm provides at least one capex guidance for the fiscal year $\mathrm{t}$, and zero otherwise. NForecast is the number of capex guidance made by firm i for fiscal year t. Forecast Range measures capex forecast precision as the absolute value of the difference between the upper and lower bounds of range capex forecasts. For a point forecast, the upper and lower bounds of the forecast range are equal, so Forecast Range is zero. Forecast Error measures capex forecast accuracy as the absolute value of the difference between management forecasted capex and actual capex. We use midpoint for range forecasts. We scale Forecast Error and Forecast Range by beginning of year net property, plant, and equipment. ${ }^{16}$ Permanent Finance Committee $_{i, t}$ and Temporary Finance Committee $_{i, t}$ were defined previously.

\footnotetext{
${ }^{16}$ For multiple forecasts made for the same fiscal year, we use both average and initial forecast, but report only the results with average value. The results are qualitatively similar when initial forecast errors and precision are calculated using initial forecasts.
} 
For the issuance of guidance and number of forecasts, we predict positive $\sigma_{1}$ and $\sigma_{2}$ because more forecasts and more frequent updates guide investors better. For the forecast accuracy and precision, we predict negative $\sigma_{1}$ and $\sigma_{2}$ because smaller forecast error (forecast range) indicates more accurate (precise) guidance.

We follow prior studies (Lu and Tucker 2012; Ali, Fan and Li 2018) and control for firm performance (ROA and Loss), firm size (LogAsset), investment opportunity (TobinQ), leverage (Leverage), firm performance uncertainty proxied by stock returns volatility and analyst earnings forecast dispersion (Ret Volatility and Analyst Dispersion), information demand from analysts and institutional shareholders (Analyst Following and InstOwn), asset tangibility (Tangible), and investment volatility (Invest Volatility). We include number of committees (NCommittees) and board size (Board Size) because these two variables are correlated with having a finance committee. As in earlier models, we include industry and year fixed effects, and cluster standard errors by firm.

\subsubsection{Empirical results}

Since our sample changes again, Panel A of Table 5 lists descriptive statistics for the capex guidance sample. The descriptive statistics indicate that firms in the capex guidance sample are larger and healthier than the firms in the investment efficiency analysis. Other firm characteristics are generally similar. In Panel B, we compare four proxies for capex guidance quality across three groups: firms without a finance committee, firms with a temporary finance committee, and firms with a permanent finance committee. Although the differences are in the predicted direction, most of the differences are not statistically significant. Only in the change in number of forecasts, firms with a temporary committee appear to increase frequency more than the other two groups.

In Panel C, we present the results of Logit (for binary variable of capex Issuance) and OLS (for all the other continuous dependent variables) regressions. Although the coefficients on our main 
variables, Permanent Finance Committee and Temporary Finance Committee, generally have the predicted sign, they are not statistically significant. Only in column (2) where the dependent variable is NForecast, the 0.517 coefficient on Temporary Finance Committee indicates that firms with a temporary finance committee provide 0.5 more forecast than do firms without a finance committee. This increase seems quite large given that the standard deviation of number of forecasts is 2.36 .

The effects of control variables are generally consistent with prior studies. Firms in a more uncertain environment (Analyst Dispersion) tend to provide less frequent, less accurate and less precise forecasts. Capital-intensive firms (Tangible) and large firms (LogAsset) are more likely to issue capex forecasts that are more accurate and precise.

\section{Additional analysis}

The empirical results in the tests of investment efficiency and capex guidance imply no strong average impact of having a finance committee on investment performance. In this section, we run several subsample analyses to test whether the impacts are context-specific.

First, we use a narrower definition of a finance committee. As we focus on investment performance, we exclude committees that are less related to investment. Specifically, among the twelve keywords we use to identify finance committees, we select only "finance", "invest", "acquisition", "M\&A", and "merger."17 The new variables are labeled as Permanent Investment Committee and Temporary Investment Committee. We expect the impact of investment committees on investment is stronger than that of finance committees more broadly because some finance committees (e.g., pensions committee) might not be involved in investment decisions.

\footnotetext{
${ }^{17}$ We continue to include "financ" because "finance committees" seem to have broad functions including investment as well as other non-investment related matters as reported in the proxy statements (see Appendix A and B).
} 
Second, we examine whether the impact of a finance committee is concentrated in adopting years. In the consequences analysis, the empirical results suggest that only temporary committees affect investment performance. Temporary committees might be more purpose-driven than permanent committees because directors organize the committee to solve a specific problem and then dissolve the committee once the goal is achieved. similarly, the influence of finance committees might be stronger in earlier years if boards create a committee to deal with current issues. Therefore, we introduce an additional indicator variable, Finance Committee Adopt Year, which is equal to one if it is the first year of having a finance committee.

Third, we examine whether finance committee size is associated with the impact of having a finance committee. More directors on a finance committee (up to some point) are likely to enhance committee performance. We use size of a finance committee, measured by number of directors in a finance committee divided by total number of directors on boards, as a proxy for committee involvement. ${ }^{18}$ This proxy measures how much weight is given to a finance committee. We create indicator variables, Large Finance Committee (Small Finance Committee) which takes a value of one if committee size is above (below) median, and zero otherwise. The baseline group is firms without finance committees.

Fourth, we examine whether finance committee composition affects outcomes. For example, financial expertise might help finance committee members improve firm investment performance. We calculate the proportion of financial experts on finance committees, and create an indicator, Strong Finance Committee (Weak Finance Committee), which equals to one if the proportion of financial experts in the finance committee is above (below) the median, and zero otherwise. ${ }^{19}$ The baseline group is firms without finance committees.

\footnotetext{
${ }^{18}$ Number of committee meetings would be a more direct measure of committee activity. Unfortunately, this information is not readily available on BoardEx and would require manual collection of data.

${ }^{19}$ We use a broad definition that includes accounting experts, finance experts, directors with an MBA degree, and directors who are identified as financial experts in BoardEx (see Section 4.2).
} 
Table 6 presents the results of additional analyses. In Panel A, we examine investment efficiency as consequences. For indicator dependent variable in column (1), the coefficient on temporary investment committee is -0.319 with marginal effects of -0.079 , indicating that firms with a temporary investment committee are 7.9 percent less likely to invest inefficiently. This is stronger than the marginal effect of 6.7 percent for Temporary Finance Committee in Table 4, Panel C. For change variable in column (5), Permanent Investment Committee shows significantly negative coefficient unlike in Table 4. These results support our prediction that investment committees are more directly associated with investment performance than finance committees. In column (2), Finance Committee Adopt Year has a positive coefficient (0.275), which contradicts our expectation. In column (6), Finance Committee Adopt Year shows negative coefficient (-1.356), suggesting that decrease in investment inefficiency might be more concentrated in the first year. Although we find some evidence supporting for stronger impacts of investment committees and adopting years, the results are not consistent across models. ${ }^{20}$

None of the coefficients on Large Finance Committee, Small Finance Committee, Strong Finance Committee, and Weak Finance Committee is significant, suggesting that committee size and composition are not as important in determining the impact of finance committees.

The results of additional analyses on capex guidance are presented in Panel B. We show only forecast errors (level and change) as a dependent variable. Temporary Investment Committee show significantly negative coefficients unlike Temporary Finance Committee in Table 5, suggesting that investment committees might be more highly related to investment performance than finance committees. All other variables are not significant except for Strong Finance Committee in column (8). Overall, only the prediction on investment committees is somewhat supported by our empirical results, and committee size and composition do not seem to provide different impacts.

\footnotetext{
${ }^{20}$ We run the same model using the continuous investment inefficiency variable as the dependent variable but none of the coefficients on the variables of interest are statistically significant (not-tabulated).
} 


\section{Conclusion}

We examined the determinants and consequences of finance committee use. Proxy statements suggest that finance committees are created deliberately with a goal of overseeing and advising management on financial issues. We predicted that complex firms with intense finance-related work are more likely to have a finance committee. Consistent with our prediction, we find that use of derivative and defined benefit pension plans, high leverage and credit rating, and active dividend payout are positively associated with the existence of a finance committee.

Next, we investigated whether companies benefit from having a finance committee. We argued that bringing together a group of financial experts in a finance committee will guide management better and ultimately improve financial performance. We examined the impact of having a finance committee on investment efficiency and quality of capex guidance. We showed that firms with a temporary finance committee invest more efficiently and provide more frequent capex guidance. The empirical results do not show significant association between the use of finance committees and capex forecast accuracy and precision. We infer from the limited evidence that finance committees improve investment decisions but not by much.

We expect this study to advance our understanding of board dynamics. The active use of finance committees by firms in great need of finance expertise suggests that boards are not simply a static governance form. Rather, we provide evidence that boards evolve to respond to new environments and to perform their monitoring and advisory roles.

We restrict our sample to unregulated industries in this study. Given the high proportion of finance committees and existing requirement for a risk committee in financial industry, separate study of finance committee use in regulated industries will add to our understanding of boards. We leave this to future research. 


\section{References}

Adams, Ragunathan, Rumarkin (2017). Death by committee? An analysis of delegation in corporate boards. Working paper, available at SSRN: https://papers.ssrn.com/sol3/papers.cfm?abstract id=2736027.

Ali, A., Fan, Z., \& Li, N. (2018). The role of capital expenditure forecasts in debt contracting. Working paper, available at SSRN: https://papers.ssrn.com/sol3/papers.cfm?abstract id=3036266.

Ashbaugh-Skaife, H., Collins, D. W., \& LaFond, R. (2006). The effects of corporate governance on firms' credit ratings. Journal of Accounting and Economics, 42(1-2), 203-243.

Badolato, P. G., Donelson, D. C., \& Ege, M. (2014). Audit committee financial expertise and earnings management: The role of status. Journal of Accounting and Economics, 58(2-3), 208-230.

Bae, J., Biddle, G. C., \& Park, C. W. (2018). Voluntary capex guidance, analyst feedback and capital investment efficiency. Analyst Feedback and Capital Investment Efficiency (July 22, 2018).

Bamber, L. S., Jiang, J., \& Wang, I. Y. (2010). What's my style? The influence of top managers on voluntary corporate financial disclosure. The Accounting Review, 85(4), 1131-1162.

Bartram, S. M., Brown, G. W., \& Fehle, F. R. (2009). International evidence on financial derivatives usage. Financial Management, 38(1), 185-206.

Basu, S., \& Liang, Y. (2019). Director-liability-reduction laws and conditional conservatism. Journal of Accounting Research (forthcoming).

Bédard, J., Chtourou, S. M., \& Courteau, L. (2004). The effect of audit committee expertise, independence, and activity on aggressive earnings management. Auditing: A Journal of Practice \& Theory, 23(2), 13-35.

Bernard, D., Ge, W., Matsumoto, D. A., \& Toynbee, S. (2018). Firm-manager matching and the tradeoffs of CFO accounting expertise. Working paper, available at SSRN:

https://papers.ssrn.com/sol3/papers.cfm?abstract_id=2858681.

Bertrand, M., \& Schoar, A. (2003). Managing with style: The effect of managers on firm policies. The Quarterly Journal of Economics, 118(4), 1169-1208.

Biddle, G. C., \& Hilary, G. (2006). Accounting quality and firm-level capital investment. The Accounting Review, 81(5), 963-982.

Biddle, G. C., Hilary, G., \& Verdi, R. S. (2009). How does financial reporting quality relate to investment efficiency?. Journal of Accounting and Economics, 48(2-3), 112-131.

Birkett, B. S. (1986). The recent history of corporate audit committees. Accounting Historians Journal, 13(2), 109-124.

Bodnar, G. M., Hayt, G. S., Marston, R. C., \& Smithson, C. W. (1995). Wharton survey of derivatives usage by US non-financial firms. Financial Management, 24(2), 104-114.

Boone, A. L., \& Mulherin, J. H. (2017). Who monitors the monitor? The use of special committees by target firms in corporate takeovers. Journal of Corporate Finance, 44, 388-404.

Booth, J. R., \& Deli, D. N. (1999). On executives of financial institutions as outside directors. Journal of Corporate Finance, 5(3), 227-250. 
Campbell, J. L. (2015). The fair value of cash flow hedges, future profitability, and stock returns. Contemporary Accounting Research, 32(1), 243-279.

Chen, T., Harford, J., \& Lin, C. (2015). Do analysts matter for governance? Evidence from natural experiments. Journal of Financial Economics, 115(2), 383-410.

Chen, F., Hope, O. K., Li, Q., \& Wang, X. (2011). Financial reporting quality and investment efficiency of private firms in emerging markets. The Accounting Review, 86(4), 1255-1288.

Chen, K., \& Wu, A. (2016). The Structure of Board Committees. Working paper: 17-032, Harvard Business School. (https://www.hbs.edu/faculty/Publication\%20Files/17-032 22ea9e7a-4f26-4645-af3d042f2b4e058c.pdf)

Choi, J. K., Hann, R. N., Subasi, M., \& Zheng, Y. (2018). Do Analysts' Capital Expenditure Forecasts Affect Corporate Investment Efficiency? Working paper, available at SSRN: https://papers.ssrn.com/sol3/papers.cfm?abstract id=3347421.

Choi, J. J., \& Jiang, C. (2009). Does multinationality matter? Implications of operational hedging for the exchange risk exposure. Journal of Banking \& Finance, 33(11), 1973-1982.

DeAngelo, H., DeAngelo, L., \& Skinner, D. J. (2004). Are dividends disappearing? Dividend concentration and the consolidation of earnings. Journal of Financial Economics, 72(3), 425-456.

DeFond, M. L., Hann, R. N., \& Hu, X. (2005). Does the market value financial expertise on audit committees of boards of directors?. Journal of Accounting Research, 43(2), 153-193.

Denis, D. J., Denis, D. K., \& Yost, K. (2002). Global diversification, industrial diversification, and firm value. The Journal of Finance, 57(5), 1951-1979.

Derrien, F., \& Kecskés, A. (2013). The real effects of financial shocks: Evidence from exogenous changes in analyst coverage. The Journal of Finance, 68(4), 1407-1440.

Dhaliwal, D. A. N., Naiker, V. I. C., \& Navissi, F. (2010). The association between accruals quality and the characteristics of accounting experts and mix of expertise on audit committees. Contemporary Accounting Research, 27(3), 787-827.

Erickson, T., \& Whited, T. M. (2006). On the accuracy of different measures of q. Financial Management, 35(3), 5-33.

Federal Reserve System Regulation YY, Docket No 1438, Enhanced Prudential Standards and Early Remediation Requirements for Covered Companies, 77 Fed Reg 593 (January 5, 2012). https://www.federalreserve.gov/reportforms/formsreview/RegYY 20120105 ifr.pdf

Francis, J. R., \& Martin, X. (2010). Acquisition profitability and timely loss recognition. Journal of Accounting and Economics, 49(1-2), 161-178.

Franzoni, F., \& Marin, J. M. (2006). Pension plan funding and stock market efficiency. The Journal of Finance, 61(2), 921-956.

GE (2018). Notice of 2018 annual meeting \& proxy statement. https://www.sec.gov/Archives/edgar/data/40545/000120677418000752/ge_courtesy-pdf.pdf

Ge, W., Matsumoto, D., \& Zhang, J. L. (2011). Do CFOs have style? An empirical investigation of the effect of individual CFOs on accounting practices. Contemporary Accounting Research, 28(4), 11411179. 
Goodman, T. H., Neamtiu, M., Shroff, N., \& White, H. D. (2013). Management forecast quality and capital investment decisions. The Accounting Review, 89(1), 331-365.

Graham, J. R., Harvey, C. R., \& Puri, M. (2013). Managerial attitudes and corporate actions. Journal of Financial Economics, 109(1), 103-121.

Guay, W. R. (1999). The impact of derivatives on firm risk: An empirical examination of new derivative users. Journal of Accounting and Economics, 26(1-3), 319-351.

Güner, A. B., Malmendier, U., \& Tate, G. (2008). Financial expertise of directors. Journal of Financial Economics, 88(2), 323-354.

Hermalin, B. E., \& Weisbach, M. S. (2001). Boards of directors as an endogenously determined institution: A survey of the economic literature (No. w8161). National Bureau of Economic Research.

Hoitash, R., Hoitash, U., \& Kurt, A. C. (2016). Do accountants make better chief financial officers? Journal of Accounting and Economics, 61(2-3), 414-432.

Hribar, P., \& Collins, D. W. (2002). Errors in estimating accruals: Implications for empirical research. Journal of Accounting Research, 40(1), 105-134.

Jensen, M. C. (1986). Agency costs of free cash flow, corporate finance, and takeovers. The American Economic Review, 76(2), 323-329.

Kahle, K. M., \& Stulz, R. M. (2017). Is the US public corporation in trouble?. Journal of Economic Perspectives, 31(3), 67-88.

Klein, A. (1998). Firm performance and board committee structure. The Journal of Law and Economics, 41(1), 275-304.

Krishnan, J. (2005). Audit committee quality and internal control: An empirical analysis. The Accounting Review, 80(2), 649-675.

Krishnan, G. V., \& Visvanathan, G. (2008). Does the SOX definition of an accounting expert matter? The association between audit committee directors' accounting expertise and accounting conservatism. Contemporary Accounting Research, 25(3), 827-858.

Krishnan, G., \& Visvanathan, G. (2009). Do auditors price audit committee's expertise? The case of accounting versus nonaccounting financial experts. Journal of Accounting, Auditing \& Finance, 24(1), $115-144$.

Li, C., Sun, L., \& Ettredge, M. (2010). Financial executive qualifications, financial executive turnover, and adverse SOX 404 opinions. Journal of Accounting and Economics, 50(1), 93-110.

Mangena, M., \& Pike, R. (2005). The effect of audit committee shareholding, financial expertise and size on interim financial disclosures. Accounting and Business Research, 35(4), 327-349.

Mautz, R. K. and F. L. Neuman. Corporate Audit Committees: Policies and Practices. Cleveland: Ernst \& Ernst, 1977.

Pfeffer, J. (1972). Size and composition of corporate boards of directors: The organization and its environment. Administrative Science Quarterly, 218-228.

Phillips, J., Pincus, M., \& Rego, S. O. (2003). Earnings management: New evidence based on deferred tax expense. The Accounting Review, 78(2), 491-521. 
Pincus, K., Rusbarsky, M., \& Wong, J. (1989). Voluntary formation of corporate audit committees among NASDAQ firms. Journal of Accounting and Public Policy, 8(4), 239-265.

Pozen. (2018). What GE's board could have done differently. Harvard Business Review.

Reeb, D., \& Upadhyay, A. (2010). Subordinate board structures. Journal of Corporate Finance, 16(4), 469-486.

Richard Lu, H. Y., \& Wu Tucker, J. (2012). Nonearnings corporate guidance. Financial Management, 41(4), 947-977.

Skinner, D. J. (2008). The evolving relation between earnings, dividends, and stock repurchases. Journal of Financial Economics, 87(3), 582-609.

Stulz, R. M. (2004). Should we fear derivatives?. Journal of Economic Perspectives, 18(3), 173-192.

Sundaram, R. K., \& Yermack, D. L. (2007). Pay me later: Inside debt and its role in managerial compensation. The Journal of Finance, 62(4), 1551-1588.

U.S. SECURITIES AND EXCHANGE COMMISSION (SEC). FinalRule: DisclosureRequired by Sections 406 and 407 ofthe Sarbanes-Oxley Act of2002. U.S. Securities and Exchange Commission, 2003

Xie, B., Davidson III, W. N., \& DaDalt, P. J. (2003). Earnings management and corporate governance: the role of the board and the audit committee. Journal of Corporate Finance, 9(3), 295-316. 


\section{Appendix A}

GE's 2017 \& 2018 proxy statements

\section{Panel A. Excerpts from GE's 2017 proxy statement}

\section{Full Board}
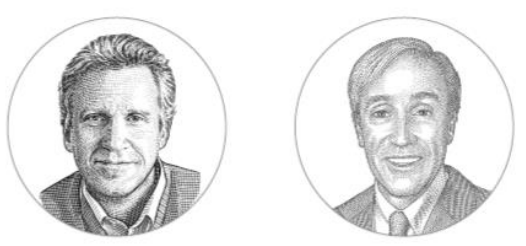

\section{A WORD FROM THE CHAIR \& THE LEAD DIRECTOR, JEFF IMMELT \& JACK BRENNAN}

In 2016, the Board focused on portfolio changes, including the planned Baker Hughes combination and Digital and Additive investments. Other priorities included:

- Alstom integration \& GE Capital exit plan progress

- Capital return vs. M\&A/organic investment

- Key GE initiatives (simplification, gross margins, cash conversion)

17 MEETINGS IN 2016

(incl. 4 independent director meetings)

\section{KEY OVERSIGHT RESPONSIBILITIES}

- Corporate strategy

- Capital allocation

- Business development

- Risk management (except as delegated to the committees)

\section{TYPICAL UPDATES AT EVERY} MEETING

- Operations (CFO)

- Global growth (CEO of GGO)

- Key businesses (rotates among business CEOs) \& initiatives (e.g., Digital \& simplificaton)

- M\&A (VP of Business Development)

Note: This panel shows a part of GE's proxy statement in 2017, the year before GE created the finance committee. We selected only the parts that are related to the finance committee and reorganized figures.

Source: https://www.sec.gov/Archives/edgar/data/40545/000120677417000738/ge_courtesy-pdf.pdf (p.21) 


\section{Panel B. Excerpts from GE's 2018 proxy statement}

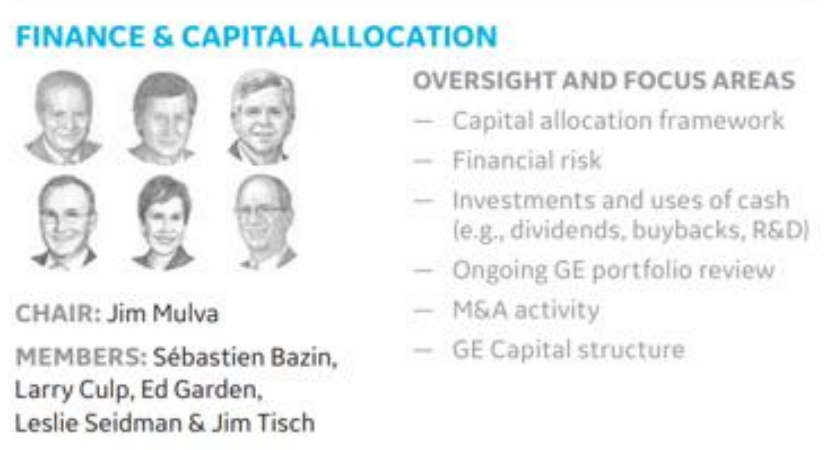

\section{WHAT'S CHANGED SINCE OUR LAST PROXY STATEMENT?}

\section{New Finance \& Capital Allocation}

Committee. The Board decided to create the committee, which began meeting in December 2017, to assist in the oversight of significant M\&A activity and other capital allocation decisions, such as investments (including R\&D), buybacks and dividends.

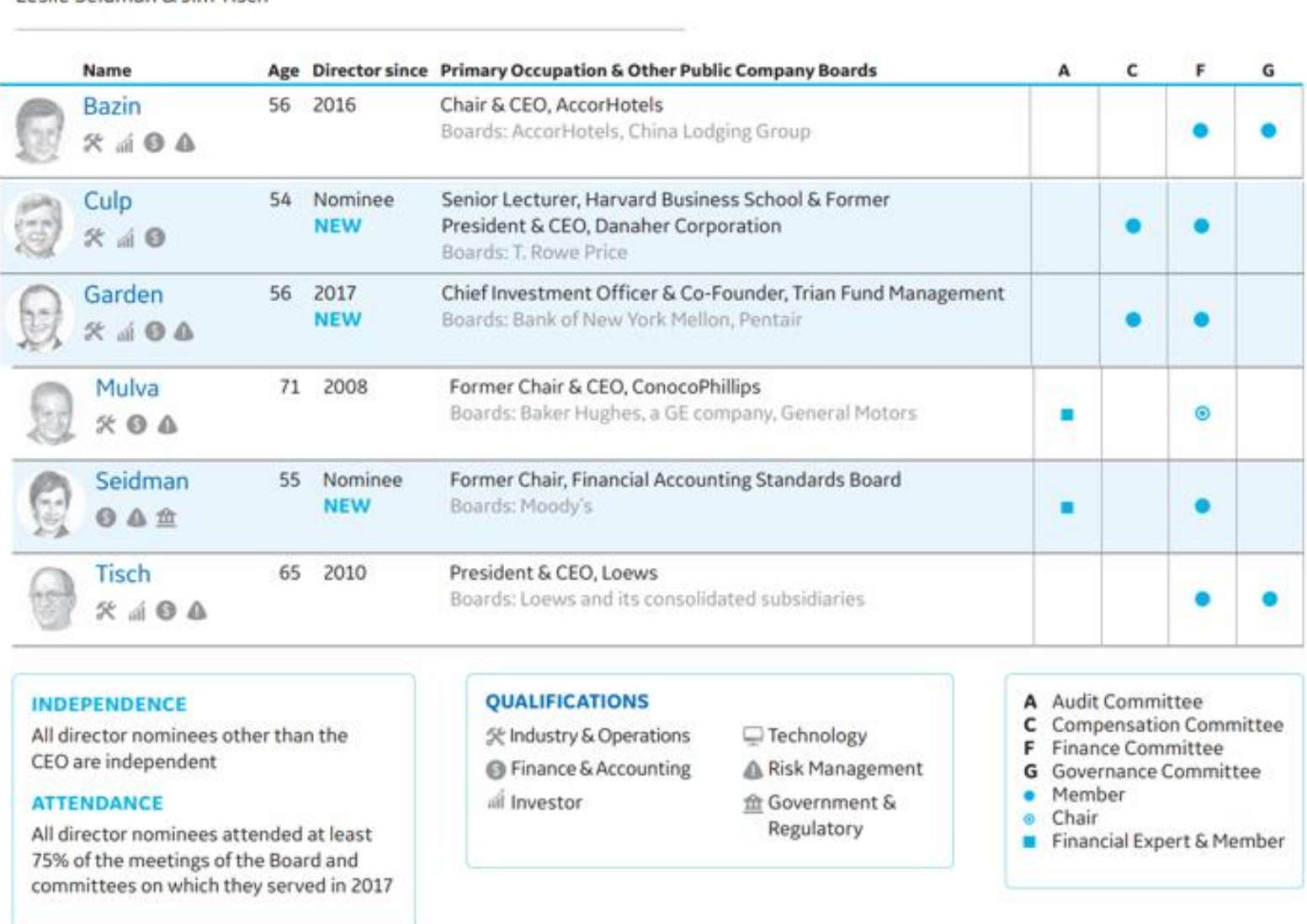

(Source: https://www.sec.gov/Archives/edgar/data/40545/000120677418000752/ge_courtesy-pdf.pdf).

Note: Above panel shows experts from GE's 2018 proxy statement $(\mathrm{p} .3,4,17)$. We selected only the parts that are related to the finance committee and reorganized figures. Below table shows how each directors' financial expertise is coded in our sample.

\begin{tabular}{|l|r|r|r|r|}
\hline \multicolumn{1}{|c|}{ Director Name } & \multicolumn{1}{|c|}{ MBA } & \multicolumn{1}{|c|}{ Accounting expert } & \multicolumn{1}{|c|}{ Finance expert } & Finance or Accounting Expert \\
\hline Jim Mulva & 1 & 0 & 1 & 1 \\
\hline Ed Garden & 0 & 0 & 1 & 1 \\
\hline Jim Rohr & 1 & 0 & 0 & 1 \\
\hline Jim Tisch & 1 & 0 & 0 & 1 \\
\hline Larry Culp Jr & 1 & 0 & 0 & 1 \\
\hline Leslie Seidman & 0 & 1 & 0 & 1 \\
\hline Sébastien Bazin & 0 & 0 & 0 & 0 \\
\hline
\end{tabular}




\section{Appendix B \\ Examples of key responsibilities of finance committees}

FOSSIL GROUP (2009)

(https://www.sec.gov/Archives/edgar/data/883569/000104746909004056/a2192221zdef14a.htm)

The Board of Directors (the "Board") has established a Finance Committee (the "Committee") for the purpose of overseeing all areas of corporate finance for Fossil Group, Inc. and its subsidiaries (the "Company"), including:

- capital structure;

- $\quad$ equity and debt financings;

- capital expenditures; cash management;

- banking activities and relationships; investments;

- foreign exchange activities; and

- $\quad$ share repurchase activities.

VERIZON COMMUNICATIONS INC (2014)

(https://www.sec.gov/Archives/edgar/data/732712/000119312514102273/d633245ddef14a.htm)

In 2013, Verizon agreed to purchase the remaining interest in Verizon Wireless that it did not already own. Because the Company was going to incur significant additional debt in order to complete this acquisition, the Board determined that it should increase its oversight of the Company's cash flows and liquidity through the creation of a Finance Committee of Directors with significant financial expertise.

Summary of Key Responsibilities:

- Review Verizon's capital management policies, plans and activities;

- Monitor Verizon's capital needs and financing arrangements and ability to access the capital markets;

- Monitor expenditures under the annual capital plan approved by the Board;

- Review Verizon's policies and strategies for managing currency and interest rate exposure and the use of derivatives;

- Review and approve Verizon's policies regarding the usage of the end user exception from the mandatory clearing and exchange trading requirements for certain swaps under the Dodd-Frank Wall Street Reform and Consumer Protection Act;

- Review Verizon's insurance and self-insurance programs; and

- Review Verizon's policies, strategy and performance with respect to the investment of pension assets and the funding of pension and other postretirement benefit obligations.

COCA COLA CO (2005)

(https://www.sec.gov/Archives/edgar/data/21344/000104746905005630/a2151220zdef14a.htm)

Under the terms of its charter, the Finance Committee is appointed to assist the Board in discharging its responsibilities relating to oversight of the Company's financial affairs. In fulfilling its duties, the Finance Committee, among other things, shall:

- formulate and recommend for approval to the Board of Directors the financial policies of the Company;

- maintain oversight of the budget and financial operations of the Company;

- review and recommend capital expenditures;

- evaluate the performance of and returns on approved capital expenditures; and

- recommend dividend policy to the Board. 
HOME DEPOT INC (2013)

(https://www.sec.gov/Archives/edgar/data/354950/000119312513145982/d451582ddef14a.htm)

In February 2012, the Board approved the creation of a Finance Committee and dissolution of the Infrastructure Committee, effective May 1, 2012. The functions of the Finance Committee will include overseeing the management of the Company's capital structure, financial resources and related financial risks to effectively support the Company's long-range strategic and operational objectives while maintaining a sound financial condition. Committee functions:

- Oversees the management of the Company's capital structure, financial resources and related financial risks to effectively support the Company's long-range strategic and operational objectives while maintaining the Company's sound financial condition

- Reviews and recommends policies, practices and strategies concerning financial matters, including the Company's management of financial risk, capital structure, investments and insurance

- Oversees the Company's annual capital plan, significant capital investments and strategies with respect to mergers and acquisitions activity

TIFFANY \& CO. (2009)

(https://www.sec.gov/Archives/edgar/data/98246/000095012309006323/y75709def14a.htm)

In May 2008, the Board formed the Finance Committee to assist the Board with its oversight of the Company's capital structure, dividend policy, repurchase of the Company's capital stock, debt and equity financings, and the retention of investment bankers and other financial advisors to the Board. The Finance Committee operates under the charter adopted by the Board. The charter may be viewed on the Company's website, http://investor.tiffany.com/governance.cfm.

LYONDELLBASELL INDUSTRIES NV (2017)

(https://www.sec.gov/Archives/edgar/data/1489393/000119312517113698/d350517ddef14a.htm)

It is the duty of the Finance Committee to assist the Supervisory Board in its oversight responsibilities by monitoring and assessing such matters as the Company's capital structure and allocation, debt portfolio, and derivative strategies. In fulfilling its duties, the Finance Committee has the following responsibilities:

- Strategy - Review analyses and provide guidance and advice regarding acquisitions and divestments and discuss and review the Company's tax strategies, planning and related structures;

- Capital - Review the Company's capital structure; review capital allocation, including organic or inorganic investments, review and discuss the dividend policy; review and discuss stock repurchase activities and plans; and

- Securities and Financing - Review and discuss the Company's debt portfolio, credit facilities, compliance with financial covenants; review and discuss the commodity, interest rate or currency derivative strategies; review and discuss the securities offerings.

Note: This appendix shows main duties of finance committees from several proxy statements of different firms. We develop our hypotheses on finance committee determinants mainly based on proxy statements. Therefore, we highlight keywords that support each hypothesis using different font colors:

H1 (Financial complexity); H2 (Debt financing); H3 (Payout policy); H4 (Investments). 


\section{Appendix C \\ Variable definitions}

Variables for finance committee determinants analyses

\begin{tabular}{|c|c|}
\hline Variable name & Variable definitions [source] \\
\hline Finance Committee & $\begin{array}{l}\text { An indicator variable that equals one if the board of directors has a finance } \\
\text { committee and zero otherwise. [BoardEx] }\end{array}$ \\
\hline Permanent Finance Committee & $\begin{array}{l}\text { An indicator variable that equals one if the finance committee lasts for over } \\
80 \text { percent of the time from the adoption year to the end of sample period and } \\
\text { zero otherwise. [BoardEx] }\end{array}$ \\
\hline Temporary Finance Committee & $\begin{array}{l}\text { An indicator variable that equals one if the finance committee lasts for less } \\
\text { than } 80 \text { percent of the time from the adoption year to the end of sample } \\
\text { period and zero otherwise. [BoardEx] }\end{array}$ \\
\hline Derivative User & $\begin{array}{l}\text { An indicator variable that equals } 1 \text { if the firm reports non-missing or nonzero } \\
\text { unrealized derivative gain or loss. } \\
\text { [Compustat items AOCIDERGL, CIDERGL] }\end{array}$ \\
\hline Foreign & $\begin{array}{l}\text { An indicator variable that equals } 1 \text { if the firm reports non-missing or nonzero } \\
\text { foreign exchange income and zero otherwise. [Compustat data FCA] }\end{array}$ \\
\hline DBplan User & $\begin{array}{l}\text { An indicator variable that equals one if the firm reports non-missing or } \\
\text { nonzero projected benefit obligation. [Compustat items PBPRO, PBPRU] }\end{array}$ \\
\hline Deferred Tax & Deferred tax rate scaled by total assets. [Compustat items TXDI/AT] \\
\hline Leverage & $\begin{array}{l}\text { Ratio of total debt to equity. } \\
\text { [Compustat items (DLC +data DLTT)/(data PRCC_F*dataCHSO)] }\end{array}$ \\
\hline Ratings & $\begin{array}{l}\text { Long-term issuer credit ratings compiled by Standard \& Poor's and reported } \\
\text { on Compustat [Compustat item SPLTICRM]. }\end{array}$ \\
\hline Debt Financing & $\begin{array}{l}\text { Net debt financing measured as the cash proceeds from the issuance of long- } \\
\text { term debt less cash payments for long-term debt reductions less the net } \\
\text { changes in current debt, deflated by total assets. } \\
\text { [Compustat items (DLTIS-DLTR-DLCCH)/AT] }\end{array}$ \\
\hline Div Payer & $\begin{array}{l}\text { An indicator variable that equals one if a firm has nonzero dividends. } \\
\text { [Compustat DVC] }\end{array}$ \\
\hline Repurchase & $\begin{array}{l}\text { An indicator variable that equals one if the increase in common treasury } \\
\text { stock (Compustat item TSTKC) is not zero or missing. If treasury stock is } \\
\text { zero, we measure repurchases as the difference between stock purchases } \\
\text { (Compustat item PRSTKC) and stock issuances (Compustat item SSTK) } \\
\text { from the statement of cash flows. If either of these amounts is negative or } \\
\text { missing, repurchases are set to zero. [Compustat] }\end{array}$ \\
\hline CAPEX & Ratio of capital expenditure to total assets. [Compustat items CAPX/AT] \\
\hline$R \& D$ & $\begin{array}{l}\text { Ratio of research and development (R\&D) expenditure to total assets. } R \& D \\
\text { expenditure is set to zero if missing. [Compustat items XRD/AT] }\end{array}$ \\
\hline Acquisition & $\begin{array}{l}\text { An indicator variable that equals one if the firm reports non-missing or } \\
\text { nonzero acquisition expenditure. [Compustat item AQC] }\end{array}$ \\
\hline Divestiture & $\begin{array}{l}\text { An indicator variable that equals one if a company reports discontinued } \\
\text { operations and zero otherwise. [Compustat item DO] }\end{array}$ \\
\hline Restructure & $\begin{array}{l}\text { An indicator variable that equals to } 1 \text { if at least one of Compustat annual data } \\
\text { items RCP, RCA, RCEPS, or RCD is not equal to } 0 \text {. [Compustat] }\end{array}$ \\
\hline Board Size & Total number of directors on the board. [BoardEx] \\
\hline Board Independence & Percentage of non-executive directors on the board. [BoardEx] \\
\hline $\log M V E$ & $\begin{array}{l}\text { Log of market value where market value is fiscal year-end stock price times } \\
\text { the number of shares outstanding. [Compustat items PRCC_F*CSHO] }\end{array}$ \\
\hline$R O A$ & $\begin{array}{l}\text { Ratio of operating income before depreciation to total assets. } \\
\text { [Compustat items OIBDP/AT] }\end{array}$ \\
\hline Firm Age & Number of years since the company was listed in a stock exchange. [CRSP] \\
\hline
\end{tabular}




\begin{tabular}{|l|l|}
\hline Ret Volatility & $\begin{array}{l}\text { Return volatility, defined as the standard deviation of monthly stock returns } \\
\text { in the fiscal year. [CRSP data RET] }\end{array}$ \\
\hline InstOwn & $\begin{array}{l}\text { Percentage of shares outstanding held by institutional investors. [Thompson } \\
\text { Reuters] }\end{array}$ \\
\hline Accounting expert CEO $(\mathrm{CFO})$ with $M B A$ & $\begin{array}{l}\text { An indicator that equals one if the CEO (CFO) has an MBA degree and zero } \\
\text { otherwise. [BoardEx] }\end{array}$ \\
\hline $\begin{array}{l}\text { An indicator that equals one if the CEO (CFO) has accounting expertise and } \\
\text { zero otherwise. We search for "CPA," "accounting," "accountant," } \\
\text { "accountancy," "audit," "controller," "internal control," "financial report." in } \\
\text { education, qualification, and prior employment history of directors to identify } \\
\text { accounting expertise. [BoardEx] }\end{array}$ \\
\hline Finance expert CEO $(C F O)$ & $\begin{array}{l}\text { An indicator that equals one if the CEO (CFO) has finance expertise and zero } \\
\text { otherwise. We search for "finance," "invest," "asset," "capital," "credit," } \\
\text { "budget," "bank," "treasur" in education, qualification, and prior employment } \\
\text { history of directors to identify finance expertise. [BoardEx] }\end{array}$ \\
\hline
\end{tabular}

Variables for finance committee consequences analyses

\begin{tabular}{|c|c|}
\hline Variable name & Variable definitions [source] \\
\hline $\begin{array}{l}\text { Investment Inefficiency } \\
\text { (Continuous variable) }\end{array}$ & $\begin{array}{l}\text { Absolute value of the residual from a regression of a firm's total investment on } \\
\text { sales growth. The regressions are estimated by industry and year for industry- } \\
\text { year with at least } 30 \text { available observations. Total investment is the sum of } \\
\text { R\&D expenditure (Compustat item XRD), capital expenditure (Compustat item } \\
\text { CAPX), and acquisition expenditure (Compustat item AQC) less cash receipts } \\
\text { from sale of property, plant, and equipment (Compustat item SPPE) multiplied } \\
\text { by } 100 \text { and scaled by total assets. Sales growth is the percentage change in } \\
\text { sales (Compustat item SALE) from year t- } 1 \text { to } 1 \text {. [Compustat] }\end{array}$ \\
\hline $\begin{array}{l}\text { Investment Inefficiency } \\
\text { (Indicator variable) }\end{array}$ & $\begin{array}{l}\text { An indicator variable that equals one if a firm has Investment Inefficiency } \\
\text { above the median and zero otherwise. [Compustat] }\end{array}$ \\
\hline Ncommittees & Total number of committees of the board. [BoardEx] \\
\hline $\log A T$ & Log of total assets. [Compustat data AT] \\
\hline Analayst Following & Number of analysts following the firm. [IBES] \\
\hline MtoB & $\begin{array}{l}\text { Ratio of the market value of total assets to book value of total assets. } \\
\text { [Compustat items (AT+PRCC_F*CSHO-CEQ-XTDB)/AT] }\end{array}$ \\
\hline OCF Volatility & $\begin{array}{l}\text { Standard deviation of cash flow from operations deflated by total assets from } \\
\text { years t-5 to } t-1 \text {. [Compustat item OANCF] }\end{array}$ \\
\hline Sales Volatility & $\begin{array}{l}\text { Standard deviation of sales deflated by total assets from years t }-5 \text { to } \mathrm{t}-1 . \\
\text { [Compustat data SALE] }\end{array}$ \\
\hline Invest Volatility & Standard deviation of total investment from years $\mathrm{t}-5$ to $\mathrm{t}-1$. [Compustat] \\
\hline Tangible & Ratio of PP\&E to total assets. [Compustat PPENT/AT] \\
\hline K-structure & $\begin{array}{l}\text { Ratio of long-term debt to the sum of long-term debt and the market value of } \\
\text { equity. [Compustat items DLTT/(DLTT+PRCC_F }{ }^{*} \text { CSHO)) }\end{array}$ \\
\hline OCF to Sale & $\begin{array}{l}\text { Ratio of cash flow from operating activities to sales. [Compustat items } \\
\text { OANCF/AT] }\end{array}$ \\
\hline Financial Slack & Ratio of cash to PPE. [Compustat items CHE/ PPENT] \\
\hline OprCycle & $\begin{array}{l}\text { Log of receivables to sales (Compustat items RECT/SALE) plus inventory to } \\
\text { COGS (Compustat items INVT/COGS) multiplied by } 360 \text {. [Compustat] }\end{array}$ \\
\hline Loss & $\begin{array}{l}\text { Indicator variable that equals one if net income before extraordinary items is } \\
\text { negative, and zero otherwise. [Compustat item IB] }\end{array}$ \\
\hline Capex Issuance & $\begin{array}{l}\text { Indicator variable that equals one if a firm provides at least one annual capex } \\
\text { guidance for fiscal year t. [I/B/E/S] }\end{array}$ \\
\hline Nforecast & Number of annual capex guidance for fiscal year t. [I/B/E/S ] \\
\hline
\end{tabular}




\begin{tabular}{|l|l|}
\hline Capex Forecast Error & $\begin{array}{l}\text { Average forecast error of all annual capex guidance issued for fiscal year t. For } \\
\text { each forecast, forecast error is measured as the absolute value of the difference } \\
\text { between the management forecasted capex minus the actual capex divided by } \\
\text { net PP\&E. For range forecasts, we use the mid-point of a range estimate. } \\
{[\mathrm{I} / \mathrm{B} / \mathrm{E} / \mathrm{S}]}\end{array}$ \\
\hline Capex Forecast Range & $\begin{array}{l}\text { Average range of all annual capex guidance issued for year t. For each forecast, } \\
\text { forecast range is measured as the absolute value of the difference between the } \\
\text { upper and lower bound of capex guidance divided by net PP\&E. For a point } \\
\text { forecast, the upper and lower bounds of the forecast range will be equal. } \\
{[\mathrm{I} / \mathrm{B} / \mathrm{E} / \mathrm{S}]}\end{array}$ \\
\hline Analyst Dispersion & Analyst earnings forecast dispersion. [I/B/E/S] \\
\hline TobinQ & $\begin{array}{l}\text { Ratio of market value of assets to book value of assets. } \\
\text { [Compustat items (AT-CEQ+PRCC_F*CSHO]/AT] }\end{array}$ \\
\hline
\end{tabular}


Figure 1

Frequency distribution of finance committees by industry

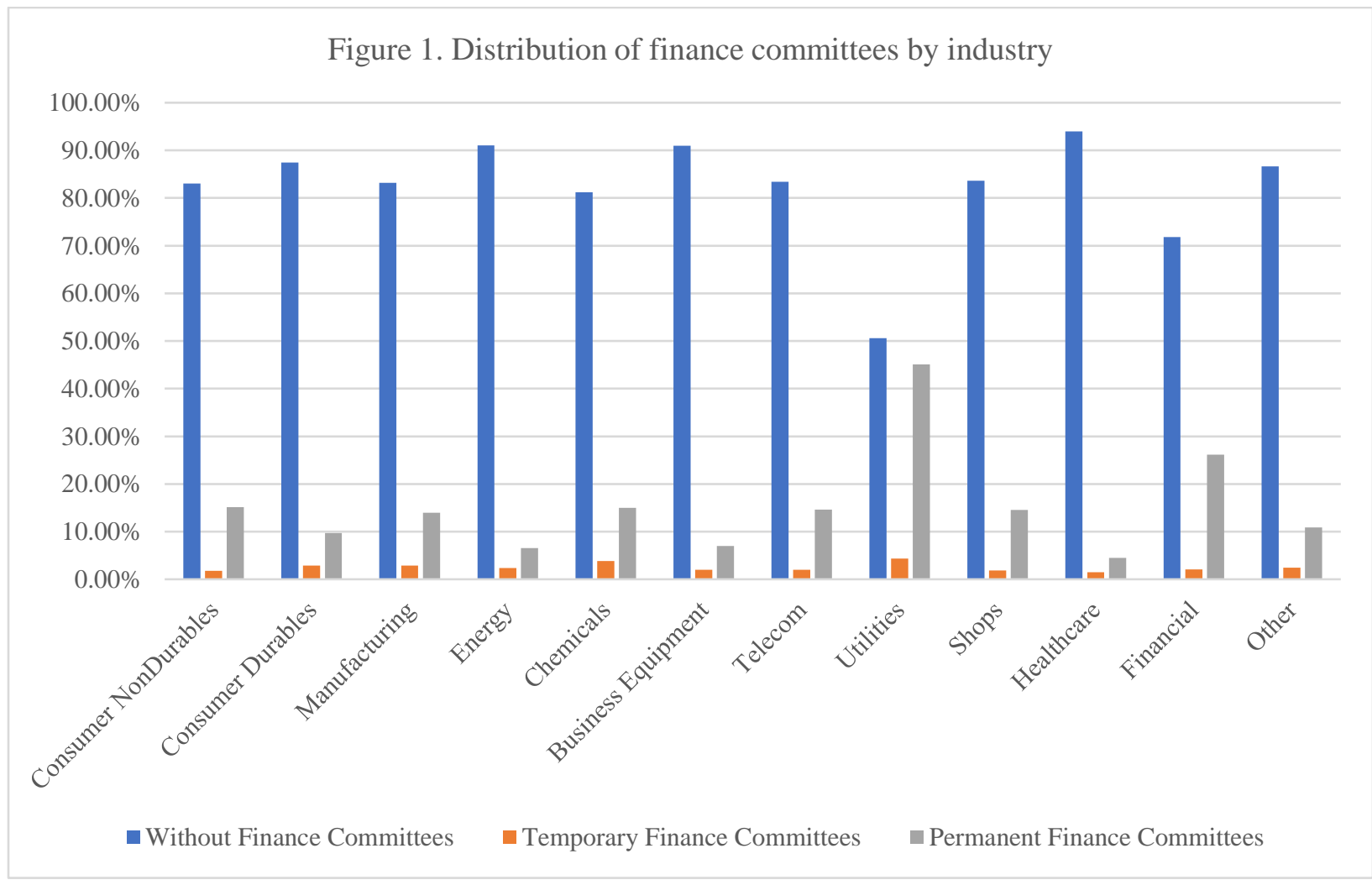

Note: This figure shows a frequency distribution of finance committees by industry. $\mathrm{X}$-axis presents industries classified by Fama and French 12 industry classification and y-axis is percentage of firms. Financial and utilities industries are labeled as regulated industry and the rest is grouped as unregulated industry in figures 1 through 3. 
Figure 2

Titles of finance committees

Panel A. Frequency distribution of finance committee titles for unregulated industries

\begin{tabular}{lr} 
Top 10 Titles of Finance Committees \\
\hline \hline Finance Committee Names & Frequency \\
\hline Finance & 3368 \\
Investments & 362 \\
Mergers and Acquisitions & 190 \\
Pensions & 168 \\
Executive and Finance & 118 \\
Risk & 113 \\
Acquisitions & 112 \\
Finance and Investment & 78 \\
Finance and Pension & 66 \\
Finance and Strategic Planning & 66 \\
\hline \hline
\end{tabular}

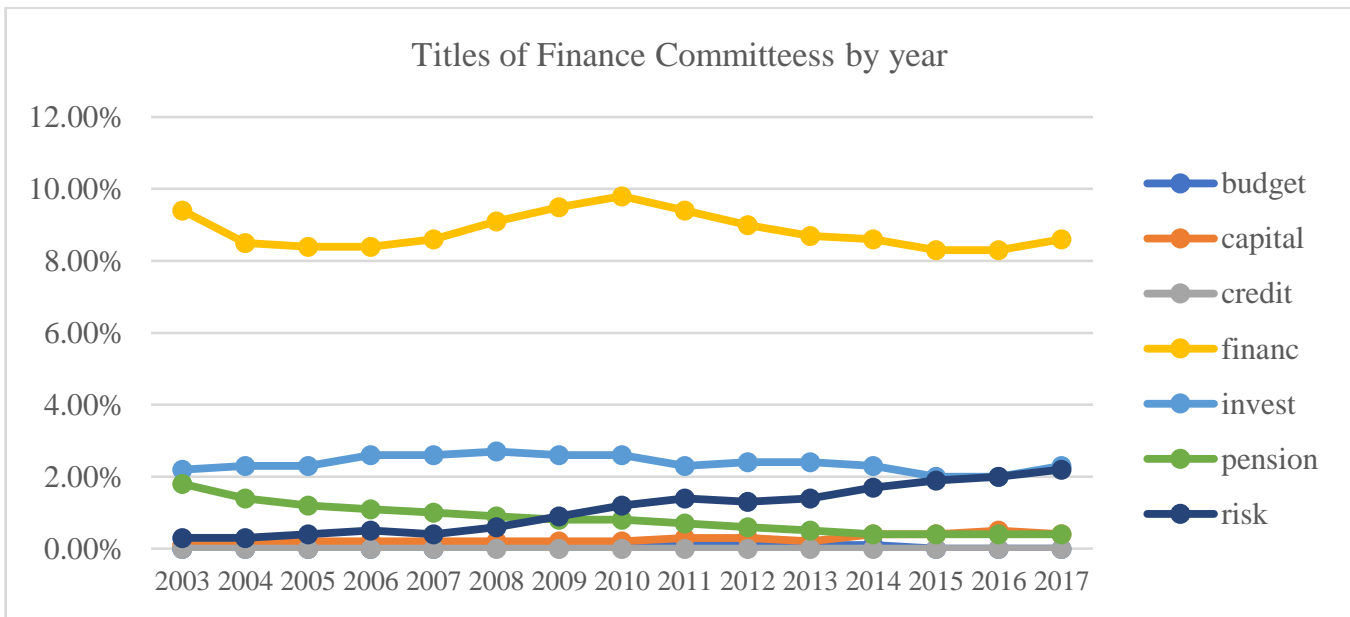

Panel B. Frequency distribution of finance committee titles for regulated industries

\begin{tabular}{lr} 
Top 10 Titles of Finance Committees \\
\hline \hline Finance Committee Names & Frequency \\
\hline Finance & 956 \\
Investments & 848 \\
Risk & 583 \\
Risk Management & 242 \\
Loans & 224 \\
Finance and Risk & 150 \\
Finance and Investment & 149 \\
Enterprise Risk Management & 133 \\
Risk Oversight & 95 \\
Assets and Liabilities Management & 88 \\
\hline \hline
\end{tabular}

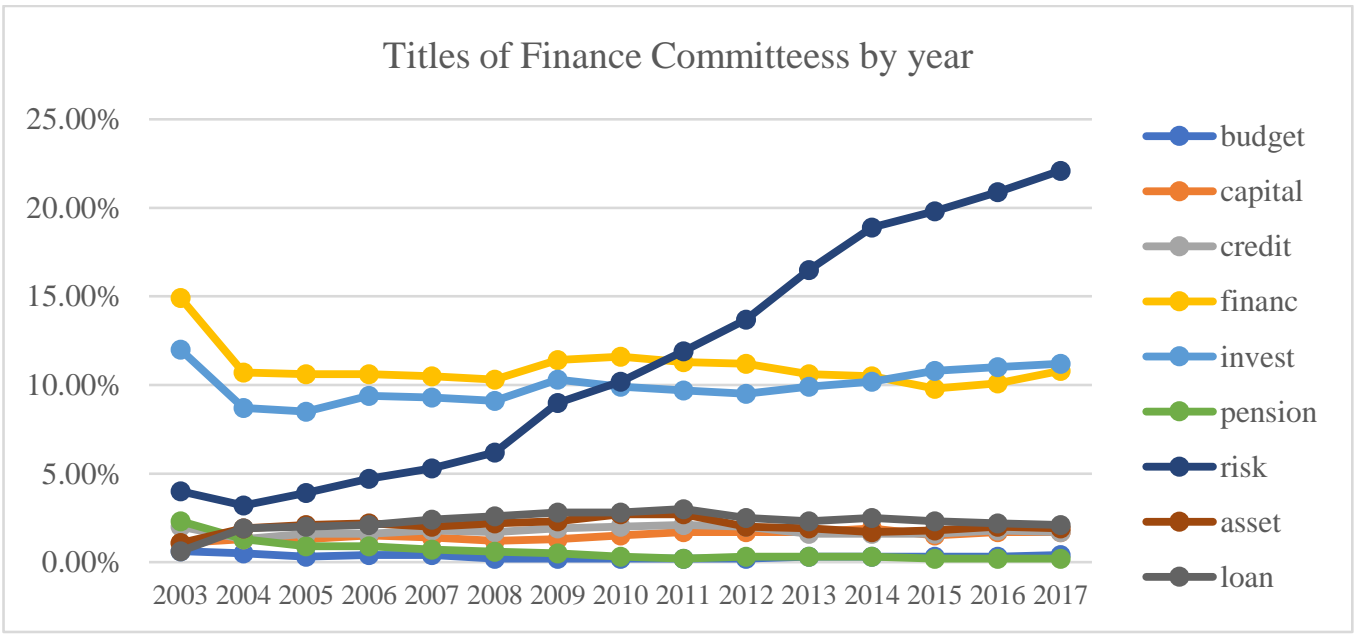




\section{Figure 3. Distributions of permanent and temporary finance committees by year}

\section{Panel A. Trend of finance committee use for unregulated industries}
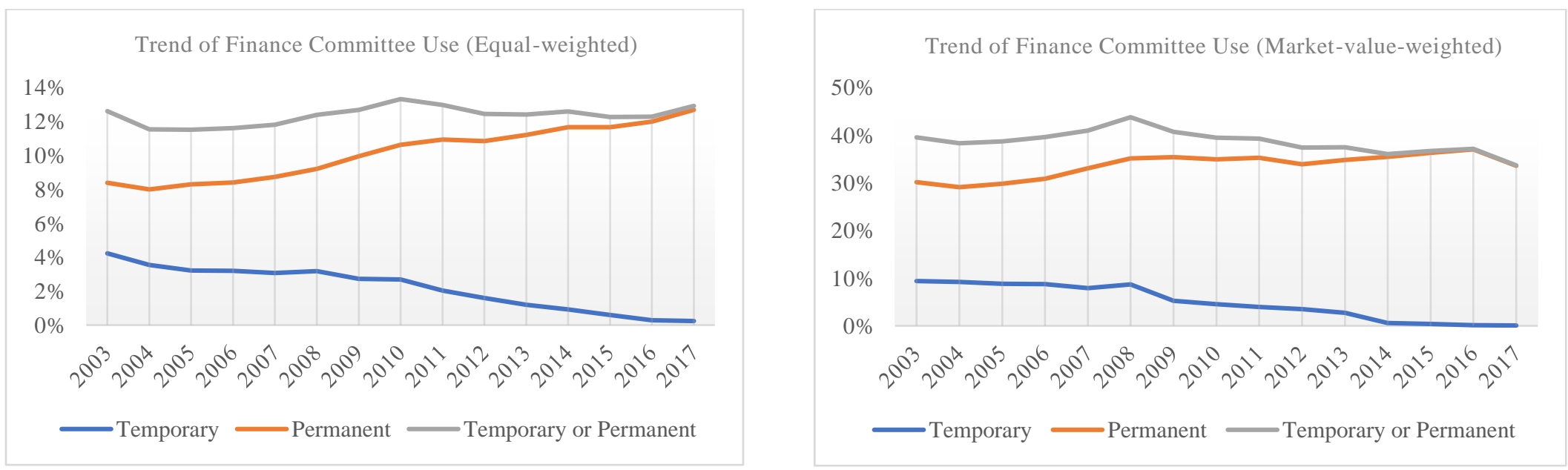

\section{Panel B. Trend of finance committee use for regulated industries}
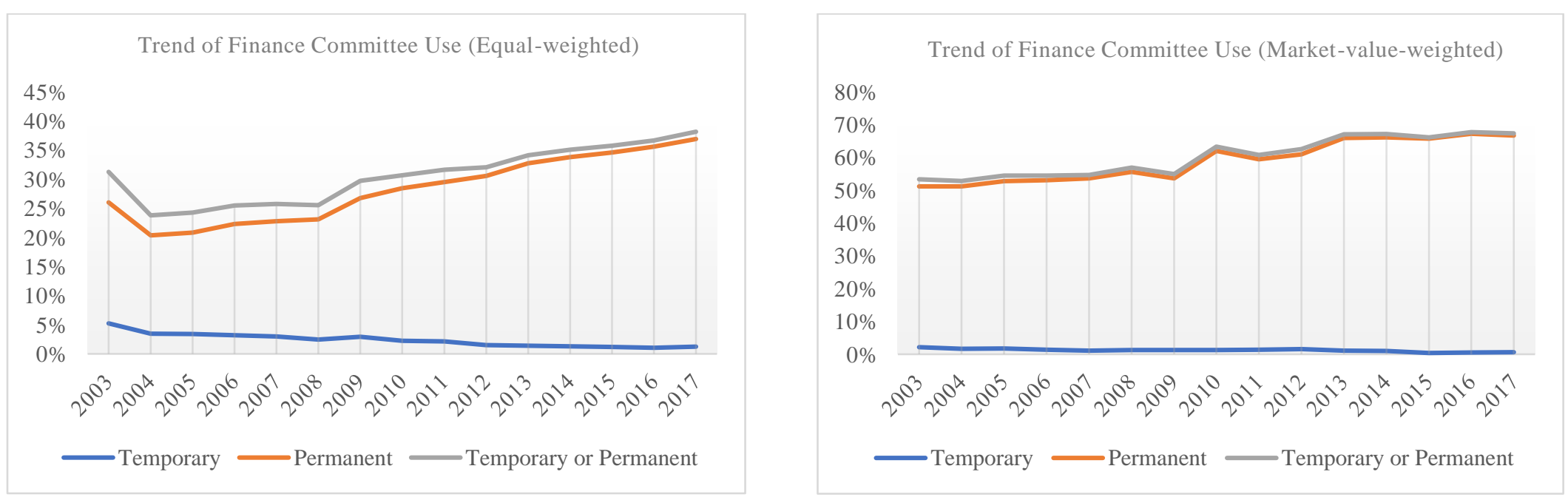

Note: In both Panels A and B, y-axis is equal-weighted (market-value weighted) proportion of firms with finance committees in the left (right) graph. 
Table 1. Sample Selection and Summary Statistics of Finance Committees

Panel A. Sample selection

Firm-year observations in BoardEx with complete data about committees (2003-2017)

82,775

(Less) Firm-years that do not link to Compustat (e.g., missing CIK)

$(14,771)$

(Less) Firm-years lacking industry code (SIC)

65,571

(Less) Firm-years for financials and utilities

$(16,643)$

(Less) Firm-years with insufficient data to construct control variables

$\underline{(11,026)}$

Final sample for analysis of the determinants

37,902

Panel B. Change in board composition in adoption years

\begin{tabular}{llll} 
& $\begin{array}{l}(1) \\
\text { Non-adoption } \\
\text { years }\end{array}$ & $\begin{array}{l}\text { (2) } \\
\text { Adoption } \\
\text { years }\end{array}$ & (1) vs. (2) \\
\hline \hline & Mean & Mean & t-stat \\
\hline Change in board size & 0.008 & 0.111 & $(1.51)$ \\
\% Change in board size & 0.008 & 0.029 & $(2.36)^{*}$ \\
Change in number of finance experts & 0.055 & 0.185 & $(3.53)^{* *}$ \\
$\%$ Change in number of finance experts & 0.045 & 0.118 & $(2.64)^{*}$ \\
Change in number of accounting experts & 0.079 & 0.208 & $(3.34)^{*}$ \\
\% Change in the number of accounting experts & 0.067 & 0.154 & $(3.27)^{*}$ \\
Change in number of supervisory experts & 0.062 & 0.664 & $(8.09)^{* * *}$ \\
\% Change in the number of supervisory experts & 0.034 & 0.197 & $(7.35)^{* * *}$ \\
Change in number of experts & 0.087 & 0.747 & $(8.26)^{* * *}$ \\
$\%$ Change in the number of experts & 0.035 & 0.201 & $(6.75)^{* * *}$ \\
\hline N & 7,039 & 337 & 7,376 \\
\hline This panel reports average changes in board size and composition for firms that ever adopted a finance committee. Non-adoption
\end{tabular}


Panel C. Comparison of audit committee and finance committee for firms with both
(1)
(2)
(3)

(4)

(1) vs. (2)

(1) vs. (3)

(1) vs. (4)

\begin{tabular}{|c|c|c|c|c|c|c|c|}
\hline & $\begin{array}{l}\text { Finance } \\
\text { Committee } \\
\end{array}$ & $\begin{array}{l}\text { Audit } \\
\text { Committee } \\
\end{array}$ & $\begin{array}{l}\text { Compensation } \\
\text { Committee } \\
\end{array}$ & $\begin{array}{l}\text { Nominating / } \\
\text { Governance } \\
\text { Committee } \\
\end{array}$ & & & \\
\hline $\mathrm{N}=4,864$ & mean & mean & mean & mean & t-stat & t-stat & t-stat \\
\hline Committee size (Number of directors) & 4.596 & 4.484 & 4.406 & 4.528 & $(5.33)^{* * *}$ & $(8.16)^{* * *}$ & $(3.38)^{* * *}$ \\
\hline Committee size $(\text { ratio })^{\mathrm{a}}$ & 0.478 & 0.472 & 0.466 & 0.475 & $(2.71)^{* * *}$ & $(5.27)^{* * *}$ & $(1.48)$ \\
\hline Percentage of accounting experts ${ }^{\mathrm{b}}$ & 0.271 & 0.358 & 0.178 & 0.168 & $(-24.59)^{* * *}$ & $(24.13) * * *$ & $(26.99)^{* * * *}$ \\
\hline Percentage of finance experts ${ }^{\mathrm{b}}$ & 0.246 & 0.266 & 0.172 & 0.164 & $(-6.26)^{* * *}$ & $(19.79) * * *$ & $(22.56) * * *$ \\
\hline Percentage of supervisory experts ${ }^{\mathrm{b}}$ & 0.807 & 0.793 & 0.827 & 0.818 & $(4.58) * * *$ & $(-5.58) * * *$ & $(-2.50)^{* *}$ \\
\hline Percentage of experts ${ }^{\mathrm{b}}$ & 0.894 & 0.905 & 0.887 & 0.872 & $(-4.37)^{* * *}$ & $(2.12)^{* *}$ & $(8.03)^{* * *}$ \\
\hline Whether chair is an expert & 0.762 & 0.908 & 0.838 & 0.791 & $(-20.51)^{* * *}$ & $(-10.11)^{* * *}$ & $(-3.09)^{* * *}$ \\
\hline Allocation of accounting experts (ratio) ${ }^{\mathrm{C}}$ & 0.564 & 0.757 & 0.359 & 0.362 & $(-26.03) * * *$ & $(24.34)^{* * *}$ & $(23.01)^{* * *}$ \\
\hline Allocation of finance experts (ratio) ${ }^{c}$ & 0.570 & 0.610 & 0.385 & 0.382 & $(-4.71)^{* * *}$ & $(19.82)^{* * *}$ & $(20.11)^{* * *}$ \\
\hline Allocation of supervisory experts $(\text { ratio })^{\mathrm{C}}$ & 0.483 & 0.472 & 0.485 & 0.486 & $(5.81)^{* * *}$ & $(1.53)$ & $(1.03)$ \\
\hline Allocation of experts (ratio) ${ }^{c}$ & 0.491 & 0.498 & 0.477 & 0.476 & $(-2.22) * *$ & $(4.27) * * *$ & $(4.09)^{* * *}$ \\
\hline
\end{tabular}

${ }^{a}$ Number of directors in each committee divided by total number of directors on the board

${ }^{b}$ Number of experts in each committee divided by total number of directors in the committee

${ }^{c}$ Number of experts in each committee divided by total number of experts on the board 
Table 2

Tests of differences in potential determinants of having a finance committee among the firms with and without finance committees

\begin{tabular}{|c|c|c|c|c|c|c|c|}
\hline & & (1) & (2) & (3) & (4) & (5) & (6) \\
\hline & & None & Temporary & Permanent & $\begin{array}{l}\text { None vs. } \\
\text { Temporary }\end{array}$ & $\begin{array}{c}\text { None vs. } \\
\text { Permanent }\end{array}$ & $\begin{array}{c}\text { Temporary vs. } \\
\text { Permanent }\end{array}$ \\
\hline & & Mean & Mean & Mean & t-stat & t-stat & t-stat \\
\hline \multirow{4}{*}{$\begin{array}{l}\text { H1. Financial } \\
\text { complexity }\end{array}$} & Derivative User & 0.350 & 0.514 & 0.606 & $(9.32)^{* * *}$ & $(31.33)^{* * *}$ & $(4.86)^{* * *}$ \\
\hline & Foreign & 0.323 & 0.348 & 0.348 & $(1.48)$ & $(3.14)^{* *}$ & $(0.01)$ \\
\hline & DBplan User & 0.321 & 0.484 & 0.684 & $(9.23)^{* * *}$ & $(46.37)^{* * *}$ & $(10.59)^{* * *}$ \\
\hline & Deferred Tax & -0.001 & -0.000 & 0.000 & $(0.95)$ & $(4.23)^{* * * *}$ & $(0.71)$ \\
\hline \multirow{4}{*}{ H2. Debt financing } & Leverage & 0.398 & 0.419 & 0.534 & $(0.67)$ & $(8.45)^{* * *}$ & $(3.25)^{* *}$ \\
\hline & Ratings & 0.763 & 1.503 & 2.373 & $(11.04)^{* * *}$ & $(49.63)^{* * *}$ & $(11.83)^{* * *}$ \\
\hline & Missing Ratings & 0.758 & 0.568 & 0.357 & $(-10.92)^{* * *}$ & $(-50.47)^{* * *}$ & $(-11.24)^{* * *}$ \\
\hline & Debt Financing & 0.013 & 0.011 & 0.014 & $(-0.40)$ & $(0.55)$ & $(0.57)$ \\
\hline \multirow{2}{*}{ H3. Payout } & Div Payer & 0.288 & 0.443 & 0.605 & $(8.87)^{* * *}$ & $(38.89)^{* * *}$ & $(8.56)^{* * *}$ \\
\hline & Repurchase & 0.243 & 0.307 & 0.367 & $(3.98)^{* * *}$ & $(15.54)^{* * *}$ & $(3.37)^{* * * *}$ \\
\hline \multirow{5}{*}{ H4. Investments } & CAPEX & 0.049 & 0.048 & 0.049 & $(-0.53)$ & $(0.37)$ & $(0.66)$ \\
\hline & $R \& D$ & 0.072 & 0.052 & 0.027 & $(-4.35)^{* * *}$ & $(-30.40) * * *$ & $(-5.17) * * *$ \\
\hline & Acquisition & 0.393 & 0.509 & 0.556 & $(6.61)^{* * *}$ & $(19.61)^{* * *}$ & $(2.46)^{*}$ \\
\hline & Divestiture & 0.143 & 0.224 & 0.248 & $(5.49) * * *$ & $(14.66)^{* * *}$ & $(1.49)$ \\
\hline & Restructure & 0.292 & 0.394 & 0.460 & $(5.94)^{* * *}$ & $(20.27)^{* * *}$ & $(3.53) * * *$ \\
\hline \multirow{2}{*}{ Board characteristics } & Board Size & 7.785 & 8.868 & 9.899 & $(14.57)^{* * *}$ & $(57.75)^{* * *}$ & $(12.66)^{* * *}$ \\
\hline & Board Independence & 80.523 & 83.980 & 86.159 & $(11.97)^{* * *}$ & $(49.11)^{* * *}$ & $(7.22)^{* * *}$ \\
\hline \multirow{5}{*}{ Firm characteristics } & $\log M V E$ & 6.089 & 6.694 & 7.839 & $(8.87)^{* * *}$ & $(52.00) * * *$ & $(15.35)^{* * *}$ \\
\hline & $R O A$ & 0.023 & 0.077 & 0.110 & $(6.64)^{* * *}$ & $(27.42)^{* * *}$ & $(4.03)^{* * *}$ \\
\hline & Firm Age & 15.940 & 23.314 & 30.029 & $(10.96) * * *$ & $(38.10)^{* * *}$ & $(8.84)^{* * *}$ \\
\hline & Ret Volatility & 0.135 & 0.121 & 0.103 & $(-5.80) * * *$ & $(-29.34) * * *$ & $(-7.17)^{* * *}$ \\
\hline & InstOwn & 0.482 & 0.509 & 0.597 & $(2.07)^{*}$ & $(19.32)^{* * *}$ & $(6.37) * * *$ \\
\hline
\end{tabular}




\begin{tabular}{|c|c|c|c|c|c|c|c|}
\hline & $\mathrm{N}$ & 33,106 & 827 & 3,969 & 33,933 & 37,075 & 4,796 \\
\hline \multirow{7}{*}{$\begin{array}{l}\text { CEOs' and CFOs' } \\
\text { background }\end{array}$} & $C E O$ with $M B A$ & 0.334 & 0.354 & 0.494 & $(0.79)$ & $(14.74)^{* * *}$ & $(5.31)^{* * *}$ \\
\hline & Accounting expert CEO & 0.105 & 0.116 & 0.092 & $(0.67)$ & $(-2.10)^{*}$ & $(-1.40)$ \\
\hline & Finance expert $C E O$ & 0.132 & 0.124 & 0.158 & $(-0.50)$ & $(3.21)^{* *}$ & $(1.84)$ \\
\hline & $C F O$ with $M B A$ & 0.439 & 0.509 & 0.480 & $(2.74)^{* *}$ & $(3.79)^{* * *}$ & $(-1.06)$ \\
\hline & Accounting expert $C F O$ & 0.729 & 0.718 & 0.691 & $(-0.45)$ & $(-3.80)^{* * *}$ & $(-1.12)$ \\
\hline & Finance expert $C F O$ & 0.694 & 0.566 & 0.691 & $(-5.01)^{* * *}$ & $(-0.29)$ & $(4.63)^{* * *}$ \\
\hline & $\mathrm{N}$ & 16,383 & 387 & 2,415 & 16,770 & 18,798 & 2,802 \\
\hline
\end{tabular}

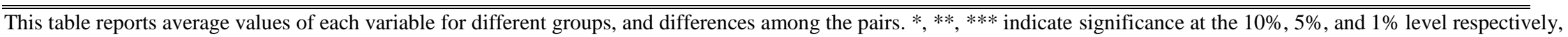
in two-tailed tests. All variables are defined in Appendix C. 
Table 3

Analysis on the determinants of having a finance committee

Panel A. Binary logit model

\begin{tabular}{|c|c|c|c|c|c|c|c|c|c|c|}
\hline & \multirow[b]{2}{*}{ VARIABLES } & \multirow[b]{2}{*}{$\begin{array}{c}\text { Pr. } \\
\text { sign }\end{array}$} & \multicolumn{4}{|c|}{$\begin{array}{l}\text { Dep.var=1 if a firm has a finance committee, } \\
\text { and } 0 \text { if a firm does not have a finance committee }\end{array}$} & \multicolumn{4}{|c|}{$\begin{array}{l}\text { Dep.var }=1 \text { if a firm has a permanent finance committee, } \\
\text { and } 0 \text { if a firm has a temporary finance committee }\end{array}$} \\
\hline & & & $\begin{array}{c}\text { (1) } \\
\text { Coefficient } \\
\end{array}$ & $\begin{array}{c}(2) \\
\text { Marginal } \\
\text { Effect } \\
\end{array}$ & $\begin{array}{c}(3) \\
\text { Coefficient } \\
\end{array}$ & $\begin{array}{c}(4) \\
\text { Marginal } \\
\text { Effect } \\
\end{array}$ & $\begin{array}{c}(5) \\
\text { Coefficient } \\
\end{array}$ & $\begin{array}{c}(6) \\
\text { Marginal } \\
\text { Effect } \\
\end{array}$ & $\begin{array}{c}(7) \\
\text { Coefficient } \\
\end{array}$ & $\begin{array}{c}(8) \\
\text { Marginal } \\
\text { Effect } \\
\end{array}$ \\
\hline $\begin{array}{l}\text { H1. Financial } \\
\text { complexity }\end{array}$ & $\begin{array}{l}\text { Derivative User } \\
\text { Foreign } \\
\text { DBplan User } \\
\text { Deferred Tax }\end{array}$ & $\begin{array}{l}+ \\
+ \\
+\end{array}$ & $\begin{array}{c}0.144 * \\
(1.67) \\
-0.179 * \\
(-1.89) \\
0.317 * * * \\
(2.93) \\
1.176 \\
(1.24) \\
\end{array}$ & $\begin{array}{c}0.013^{*} \\
(1.67) \\
-0.016^{*} \\
(-1.89) \\
0.029 * * * \\
(2.92) \\
0.108 \\
(1.24) \\
\end{array}$ & $\begin{array}{c}0.136 \\
(1.28) \\
-0.206^{*} \\
(-1.91) \\
0.269^{* *} \\
(2.05) \\
-0.511 \\
(-0.42) \\
\end{array}$ & $\begin{array}{c}0.014 \\
(1.28) \\
-0.021 * \\
(-1.91) \\
0.027 * * \\
(2.06) \\
-0.052 \\
(-0.42) \\
\end{array}$ & $\begin{array}{c}-0.078 \\
(-0.41) \\
-0.265 \\
(-1.34) \\
0.568 * * \\
(2.20) \\
3.814 \\
(1.60) \\
\end{array}$ & $\begin{array}{c}-0.009 \\
(-0.41) \\
-0.031 \\
(-1.34) \\
0.067 * * \\
(2.21) \\
0.451 \\
(1.60) \\
\end{array}$ & $\begin{array}{c}-0.056 \\
(-0.22) \\
-0.317 \\
(-1.29) \\
0.440 \\
(1.36) \\
4.506 \\
(1.33) \\
\end{array}$ & $\begin{array}{c}-0.005 \\
(-0.22) \\
-0.029 \\
(-1.29) \\
0.041 \\
(1.36) \\
0.415 \\
(1.32) \\
\end{array}$ \\
\hline $\begin{array}{l}\text { H2. Debt } \\
\text { financing }\end{array}$ & $\begin{array}{l}\text { Leverage } \\
\text { Ratings } \\
\text { Missing Ratings } \\
\text { Debt Financing }\end{array}$ & $\begin{array}{l}+ \\
+\end{array}$ & $\begin{array}{c}0.064 \\
(1.57) \\
-0.047 \\
(-0.66) \\
-0.566^{* *} \\
(-2.43) \\
-0.054 \\
(-0.39) \\
\end{array}$ & $\begin{array}{c}0.006 \\
(1.58) \\
-0.004 \\
(-0.66) \\
-0.052 * * \\
(-2.42) \\
-0.005 \\
(-0.39) \\
\end{array}$ & $\begin{array}{c}0.116^{* *} \\
(2.33) \\
-0.040 \\
(-0.48) \\
-0.445 \\
(-1.62) \\
-0.315^{*} \\
(-1.83)\end{array}$ & $\begin{array}{c}0.012 * * \\
(2.33) \\
-0.004 \\
(-0.48) \\
-0.045 \\
(-1.62) \\
-0.032 * \\
(-1.83) \\
\end{array}$ & $\begin{array}{c}0.135 \\
(1.39) \\
0.056 \\
(0.37) \\
0.011 \\
(0.02) \\
0.024 \\
(0.06) \\
\end{array}$ & $\begin{array}{c}0.016 \\
(1.38) \\
0.007 \\
(0.37) \\
0.001 \\
(0.02) \\
0.003 \\
(0.06) \\
\end{array}$ & $\begin{array}{c}0.284^{*} \\
(1.85) \\
-0.033 \\
(-0.17) \\
-0.191 \\
(-0.27) \\
0.831 \\
(1.19) \\
\end{array}$ & $\begin{array}{c}0.026^{*} \\
(1.83) \\
-0.003 \\
(-0.17) \\
-0.018 \\
(-0.27) \\
0.077 \\
(1.18) \\
\end{array}$ \\
\hline H3. Payout & $\begin{array}{l}\text { Div Payer } \\
\text { Repurchase }\end{array}$ & + & $\begin{array}{c}0.241 * * \\
(2.45) \\
0.005 \\
(0.07) \\
\end{array}$ & $\begin{array}{c}0.022 * * \\
(2.44) \\
0.000 \\
(0.07) \\
\end{array}$ & $\begin{array}{c}0.320 * * * \\
(2.72) \\
-0.071 \\
(-0.74)\end{array}$ & $\begin{array}{l}0.033 * * * \\
(2.72) \\
-0.007 \\
(-0.74) \\
\end{array}$ & $\begin{array}{c}-0.003 \\
(-0.01) \\
-0.048 \\
(-0.29) \\
\end{array}$ & $\begin{array}{c}-0.000 \\
(-0.01) \\
-0.006 \\
(-0.29) \\
\end{array}$ & $\begin{array}{c}-0.204 \\
(-0.66) \\
-0.157 \\
(-0.77)\end{array}$ & $\begin{array}{c}-0.019 \\
(-0.65) \\
-0.014 \\
(-0.77) \\
\end{array}$ \\
\hline \multirow[t]{2}{*}{$\begin{array}{l}\mathrm{H} 4 . \\
\text { Investments }\end{array}$} & $\begin{array}{l}\text { Acquisition } \\
\text { Divestiture } \\
\text { Restructure }\end{array}$ & $\begin{array}{l}+ \\
+\end{array}$ & $\begin{array}{c}1.031 \\
(1.29) \\
-0.753 \\
(-1.07) \\
0.106 \\
(1.56) \\
0.088 \\
(1.06) \\
0.008 \\
(0.12)\end{array}$ & $\begin{array}{c}0.095 \\
(1.29) \\
-0.069 \\
(-1.07) \\
0.010 \\
(1.55) \\
0.008 \\
(1.06) \\
0.001 \\
(0.12)\end{array}$ & $\begin{array}{c}1.318 \\
(1.30) \\
-0.779 \\
(-0.94) \\
0.110 \\
(1.32) \\
0.056 \\
(0.55) \\
-0.051 \\
(-0.60)\end{array}$ & $\begin{array}{c}0.134 \\
(1.31) \\
-0.079 \\
(-0.94) \\
0.011 \\
(1.32) \\
0.006 \\
(0.55) \\
-0.005 \\
(-0.60)\end{array}$ & $\begin{array}{c}2.778 \\
(1.49) \\
-1.885^{*} \\
(-1.66) \\
-0.148 \\
(-0.98) \\
0.003 \\
(0.02) \\
-0.224 \\
(-1.36)\end{array}$ & $\begin{array}{c}0.328 \\
(1.50) \\
-0.223^{*} \\
(-1.67) \\
-0.018 \\
(-0.98) \\
0.000 \\
(0.02) \\
-0.026 \\
(-1.36)\end{array}$ & $\begin{array}{c}3.977 * \\
(1.67) \\
-2.950 * \\
(-1.89) \\
-0.121 \\
(-0.60) \\
-0.171 \\
(-0.77) \\
0.005 \\
(0.02)\end{array}$ & $\begin{array}{c}0.366^{*} \\
(1.67) \\
-0.272^{*} \\
(-1.89) \\
-0.011 \\
(-0.60) \\
-0.016 \\
(-0.77) \\
0.000 \\
(0.02)\end{array}$ \\
\hline & Board Size & + & $\begin{array}{l}0.170 * * * \\
(7.35)\end{array}$ & $\begin{array}{l}0.016 * * * \\
(7.32)\end{array}$ & $\begin{array}{c}0.183 * * * * \\
(6.36)\end{array}$ & $\begin{array}{l}0.019 * * * \\
(6.41)\end{array}$ & $\begin{array}{c}0.078 \\
(1.42)\end{array}$ & $\begin{array}{r}0.009 \\
(1.42)\end{array}$ & $\begin{array}{c}0.061 \\
(0.86)\end{array}$ & $\begin{array}{c}0.006 \\
(0.87)\end{array}$ \\
\hline
\end{tabular}




\begin{tabular}{|c|c|c|c|c|c|c|c|c|c|c|}
\hline $\begin{array}{c}\text { Board } \\
\text { characteristics }\end{array}$ & Board Independence & + & $\begin{array}{l}0.040 * * * \\
(6.56)\end{array}$ & $\begin{array}{l}0.004 * * * \\
(6.59)\end{array}$ & $\begin{array}{l}0.042 * * * \\
(5.58)\end{array}$ & $\begin{array}{l}0.004 * * * \\
(5.61)\end{array}$ & $\begin{array}{c}0.008 \\
(0.60)\end{array}$ & $\begin{array}{r}0.001 \\
(0.60) \\
\end{array}$ & $\begin{array}{l}0.029 * \\
(1.86)\end{array}$ & $\begin{array}{l}0.003 * \\
(1.88)\end{array}$ \\
\hline \multirow{10}{*}{$\begin{array}{c}\text { Firm } \\
\text { characteristics }\end{array}$} & \multirow[t]{2}{*}{$\log M V E$} & \multirow[t]{2}{*}{+} & $0.098 * *$ & $0.009 * *$ & $0.123 * * *$ & $0.012 * * *$ & $0.161 * *$ & $0.019 * *$ & $0.278^{* *}$ & $0.026^{* *}$ \\
\hline & & & $(2.40)$ & $(2.41)$ & $(2.67)$ & $(2.67)$ & $(2.00)$ & $(1.98)$ & $(2.55)$ & $(2.54)$ \\
\hline & \multirow[t]{2}{*}{$R O A$} & \multirow[t]{2}{*}{+} & -0.333 & -0.031 & $-0.480 *$ & $-0.049 *$ & $-1.097 * *$ & $-0.130 * *$ & $-2.423 * * *$ & $-0.223 * * *$ \\
\hline & & & $(-1.50)$ & $(-1.50)$ & $(-1.65)$ & $(-1.66)$ & $(-2.08)$ & $(-2.08)$ & $(-2.63)$ & $(-2.63)$ \\
\hline & \multirow[t]{2}{*}{ Firm Age } & \multirow[t]{2}{*}{+} & $0.016 * * *$ & $0.002 * * *$ & $0.012 * * *$ & $0.001 * * *$ & 0.003 & 0.000 & 0.002 & 0.000 \\
\hline & & & $(5.60)$ & $(5.63)$ & $(3.62)$ & $(3.63)$ & $(0.47)$ & $(0.47)$ & $(0.30)$ & $(0.30)$ \\
\hline & \multirow[t]{2}{*}{ Ret Volatility } & \multirow[t]{2}{*}{+} & -0.118 & -0.011 & -0.055 & -0.006 & 1.164 & 0.138 & 0.904 & 0.083 \\
\hline & & & $(-0.25)$ & $(-0.25)$ & $(-0.09)$ & $(-0.09)$ & $(1.02)$ & $(1.02)$ & $(0.54)$ & $(0.53)$ \\
\hline & \multirow[t]{2}{*}{ InstOwn } & \multirow[t]{2}{*}{$?$} & -0.194 & -0.018 & -0.092 & -0.009 & 0.461 & 0.054 & $1.042 * * *$ & $0.096^{* * *}$ \\
\hline & & & $(-1.39)$ & $(-1.39)$ & $(-0.55)$ & $(-0.55)$ & $(1.50)$ & $(1.51)$ & $(2.82)$ & $(2.84)$ \\
\hline \multirow{18}{*}{$\begin{array}{l}\text { CEOs' and } \\
\text { CFOs' } \\
\text { background }\end{array}$} & \multirow[t]{2}{*}{$C E O$ with $M B A$} & \multirow[t]{2}{*}{$?$} & & & $0.437 * * *$ & $0.045^{* * *}$ & & & $0.593 * *$ & $0.055^{* *}$ \\
\hline & & & & & $(4.24)$ & $(4.24)$ & & & $(2.48)$ & $(2.47)$ \\
\hline & \multirow[t]{2}{*}{ Accounting expert } & \multirow[t]{2}{*}{$?$} & & & $-0.313 *$ & $-0.032 *$ & & & $-0.652 *$ & $-0.060 *$ \\
\hline & & & & & $(-1.78)$ & $(-1.78)$ & & & $(-1.66)$ & $(-1.65)$ \\
\hline & \multirow{2}{*}{ Finance expert CEO } & \multirow[t]{2}{*}{$?$} & & & 0.081 & 0.008 & & & 0.377 & 0.035 \\
\hline & & & & & $(0.50)$ & $(0.50)$ & & & (1.07) & (1.08) \\
\hline & \multirow[t]{2}{*}{$C F O$ with $M B A$} & \multirow[t]{2}{*}{$?$} & & & -0.023 & -0.002 & & & -0.293 & -0.027 \\
\hline & & & & & $(-0.23)$ & $(-0.23)$ & & & $(-1.22)$ & $(-1.21)$ \\
\hline & \multirow[t]{2}{*}{ Accounting expert } & \multirow[t]{2}{*}{$?$} & & & 0.121 & 0.012 & & & -0.144 & -0.013 \\
\hline & & & & & $(1.15)$ & $(1.15)$ & & & $(-0.58)$ & $(-0.57)$ \\
\hline & \multirow[t]{2}{*}{ Finance expert $\mathrm{CFO}$} & \multirow[t]{2}{*}{$?$} & & & -0.082 & -0.008 & & & $0.473 * *$ & $0.044 * *$ \\
\hline & & & & & $(-0.80)$ & $(-0.80)$ & & & $(2.04)$ & $(2.06)$ \\
\hline & \multirow[t]{2}{*}{ Constant } & & $-7.672 * * *$ & & $-8.255^{*} * *$ & & $-2.412 *$ & & $-4.952 * * *$ & \\
\hline & & & $(-12.67)$ & & $(-11.00)$ & & $(-1.82)$ & & $(-3.06)$ & \\
\hline & \multirow{4}{*}{$\begin{array}{l}\text { Observations } \\
\text { Pseudo R2 } \\
\text { Fixed Effects }\end{array}$} & & 37,902 & \multirow[t]{2}{*}{37,902} & 19,185 & \multirow[t]{2}{*}{19,185} & 4,796 & 4,796 & 2,802 & \multirow[t]{2}{*}{2,802} \\
\hline & & & 0.181 & & 0.190 & & 0.182 & & 0.247 & \\
\hline & & & Year \& & Year \& & Year \& & Year \& & Year \& & Year \& & Year \& & Year \& \\
\hline & & & Industry & Industry & Industry & Industry & Industry & Industry & Industry & Industry \\
\hline
\end{tabular}

This panel reports logit regression estimates of equation (2). The numbers in parentheses are robust z-statistics and standard errors are clustered by firm. $*, * *, * * *$ indicate significance at the $10 \%, 5 \%$, and $1 \%$ level respectively, in two-tailed tests. Industry fixed effects are classified using Fama and French 12 sectors. All other variables are defined in Appendix C. 
Panel B. Multinomial logit model (Base group: firms with no finance committees)

\begin{tabular}{|c|c|c|c|c|c|}
\hline & VARIABLES & $\begin{array}{c}\text { (1) } \\
\text { Temporary }\end{array}$ & $\begin{array}{c}(2) \\
\text { Permanent }\end{array}$ & $\begin{array}{c}(3) \\
\text { Temporary }\end{array}$ & $\begin{array}{c}\text { (4) } \\
\text { Permanent }\end{array}$ \\
\hline $\begin{array}{l}\text { H1. Financial } \\
\text { complexity }\end{array}$ & $\begin{array}{l}\text { Derivative User } \\
\text { Foreign } \\
\text { DBplan User } \\
\text { Deferred Tax }\end{array}$ & $\begin{array}{c}0.022 \\
(0.15) \\
0.000 \\
(0.00) \\
-0.115 \\
(-0.62) \\
-1.085 \\
(-0.53)\end{array}$ & $\begin{array}{l}0.156 \\
(1.56) \\
-0.214^{*} \\
(-1.93) \\
0.426^{* * *} \\
(3.39) \\
1.773^{*} \\
(1.74) \\
\end{array}$ & $\begin{array}{c}-0.006 \\
(-0.03) \\
0.009 \\
(0.04) \\
-0.213 \\
(-0.91) \\
-3.741 \\
(-1.47)\end{array}$ & $\begin{array}{c}0.146 \\
(1.22) \\
-0.239 * \\
(-1.95) \\
0.365 * * \\
(2.45) \\
0.191 \\
(0.14) \\
\end{array}$ \\
\hline H2. Debt financing & $\begin{array}{l}\text { Leverage } \\
\text { Ratings } \\
\text { Missing Ratings } \\
\text { Debt Financing }\end{array}$ & $\begin{array}{c}-0.043 \\
(-0.56) \\
-0.118 \\
(-0.91) \\
-0.699 * \\
(-1.73) \\
0.085 \\
(0.27)\end{array}$ & $\begin{array}{l}0.092 * * \\
(2.00) \\
-0.043 \\
(-0.53) \\
-0.559 * * \\
(-2.12) \\
-0.095 \\
(-0.64)\end{array}$ & $\begin{array}{c}-0.090 \\
(-0.75) \\
0.026 \\
(0.16) \\
-0.248 \\
(-0.47) \\
-0.215 \\
(-0.99) \\
\end{array}$ & $\begin{array}{c}0.153 * * * \\
(2.81) \\
-0.060 \\
(-0.66) \\
-0.497 \\
(-1.64) \\
-0.347 * \\
(-1.93) \\
\end{array}$ \\
\hline H3. Payout & $\begin{array}{l}\text { Div Payer } \\
\text { Repurchase }\end{array}$ & $\begin{array}{c}0.280 \\
(1.54) \\
0.103 \\
(0.73) \\
\end{array}$ & $\begin{array}{l}0.235 * * \\
(2.10) \\
-0.017 \\
(-0.19)\end{array}$ & $\begin{array}{c}0.552 * * \\
(2.47) \\
0.006 \\
(0.03)\end{array}$ & $\begin{array}{l}0.283 * * \\
(2.15) \\
-0.082 \\
(-0.76)\end{array}$ \\
\hline H4. Investments & $\begin{array}{l}\text { CAPEX } \\
R \& D \\
\text { Acquisition } \\
\text { Divestiture } \\
\text { Restructure }\end{array}$ & $\begin{array}{c}-0.708 \\
(-0.52) \\
0.516 \\
(0.60) \\
0.219 * \\
(1.78) \\
0.080 \\
(0.54) \\
0.143 \\
(1.05)\end{array}$ & $\begin{array}{c}1.531 \\
(1.63) \\
-1.324 \\
(-1.38) \\
0.082 \\
(1.06) \\
0.096 \\
(1.03) \\
-0.025 \\
(-0.32)\end{array}$ & $\begin{array}{c}-1.121 \\
(-0.65) \\
0.563 \\
(0.50) \\
0.232 \\
(1.45) \\
0.075 \\
(0.40) \\
-0.062 \\
(-0.34)\end{array}$ & $\begin{array}{c}1.870 \\
(1.60) \\
-1.143 \\
(-1.10) \\
0.098 \\
(1.06) \\
0.058 \\
(0.52) \\
-0.052 \\
(-0.55)\end{array}$ \\
\hline Board characteristics & $\begin{array}{l}\text { Board Size } \\
\text { Board Independence }\end{array}$ & $\begin{array}{l}0.122 * * * \\
(3.13) \\
0.037 * * * \\
(3.87)\end{array}$ & $\begin{array}{l}0.180 * * * \\
(6.76) \\
0.041^{* * *} \\
(5.67)\end{array}$ & $\begin{array}{l}0.151 * * * \\
(2.88) \\
0.029 * * \\
(2.09)\end{array}$ & $\begin{array}{l}0.187 * * * \\
(5.81) \\
0.046 * * * \\
(5.43)\end{array}$ \\
\hline Firm characteristics & $\begin{array}{l}\text { LogMVE } \\
\text { ROA }\end{array}$ & $\begin{array}{c}-0.025 \\
(-0.40) \\
0.221 \\
(0.61)\end{array}$ & $\begin{array}{l}0.134 * * * \\
(2.75) \\
-0.522 * * \\
(-1.98)\end{array}$ & $\begin{array}{c}-0.075 \\
(-0.89) \\
0.652 \\
(1.13)\end{array}$ & $\begin{array}{l}0.171 * * * \\
(3.25) \\
-0.767 * * \\
(-2.42)\end{array}$ \\
\hline
\end{tabular}




\begin{tabular}{|c|c|c|c|c|c|}
\hline & $\begin{array}{l}\text { Firm Age } \\
\text { Ret Volatility } \\
\text { InstOwn }\end{array}$ & $\begin{array}{l}0.017 * * * \\
(3.33) \\
-0.835 \\
(-1.07) \\
-0.485^{*} \\
(-1.94) \\
\end{array}$ & $\begin{array}{c}0.016^{* * *} \\
(5.00) \\
0.062 \\
(0.11) \\
-0.084 \\
(-0.51) \\
\end{array}$ & $\begin{array}{l}0.013 * * \\
(2.21) \\
0.043 \\
(0.04) \\
-0.806 * * * \\
(-2.67) \\
\end{array}$ & $\begin{array}{c}0.012 * * * \\
(3.27) \\
-0.069 \\
(-0.09) \\
0.105 \\
(0.54) \\
\end{array}$ \\
\hline \multirow{13}{*}{$\begin{array}{c}\text { CEOs' and CFOs' } \\
\text { background }\end{array}$} & $C E O$ with $M B A$ & & & -0.008 & $0.519 * * *$ \\
\hline & & & & $(-0.04)$ & $(4.51)$ \\
\hline & Accounting Expert CEO & & & $\begin{array}{c}0.158 \\
(0.59)\end{array}$ & $\begin{array}{l}-0.401^{* *} \\
(-1.98)\end{array}$ \\
\hline & Finance Expert CEO & & & -0.116 & 0.103 \\
\hline & & & & $(-0.46)$ & $(0.57)$ \\
\hline & $C F O$ with $M B A$ & & & 0.271 & -0.079 \\
\hline & & & & $(1.40)$ & $(-0.72)$ \\
\hline & Accounting Expert CFO & & & $\begin{array}{r}0.235 \\
(1.09)\end{array}$ & $\begin{array}{r}0.105 \\
(0.92)\end{array}$ \\
\hline & Finance Expert $C F O$ & & & $\begin{array}{l}-0.446 * * \\
(-2.39)\end{array}$ & $\begin{array}{r}-0.007 \\
(-0.06)\end{array}$ \\
\hline & Constant & $\begin{array}{l}-6.829 * * * \\
(-7.21)\end{array}$ & $\begin{array}{l}-8.689 \text { *** } \\
(-12.15)\end{array}$ & $\begin{array}{l}-6.282 * * * \\
(-4.64)\end{array}$ & $\begin{array}{l}-9.483^{* * * *} \\
(-11.38)\end{array}$ \\
\hline & Observations & 37,902 & 37,902 & 19,185 & 19,185 \\
\hline & Pseudo R2 & 0.181 & 0.181 & 0.197 & 0.197 \\
\hline & Fixed Effects & Year \& Industry & Year \& Industry & Year \& Industry & Year \& Industry \\
\hline
\end{tabular}

This panel reports multinomial logit regression estimates of equation (2). The numbers in parentheses are robust z-statistics and standard errors are clustered by firm. $*, * *, * *$ indicate significance at the $10 \%, 5 \%$, and $1 \%$ level respectively, in two-tailed tests. Industry fixed effects are classified using Fama and French 12 sectors. All other variables are defined in Appendix C. 
Table 4

Analysis of finance committee and investment efficiency

Panel A. Descriptive statistics for variables in our regression analyses of investment efficiency $(\mathrm{N}=5,773)$

\begin{tabular}{|c|c|c|c|c|c|}
\hline & Mean & Std & Q1 & Median & Q3 \\
\hline Permanent Finance Committee & 0.412 & 0.492 & 0 & 0 & 1 \\
\hline Temporary Finance Committee & 0.082 & 0.274 & 0 & 0 & 0 \\
\hline NCommittees & 4.266 & 1.085 & 4.000 & 4.000 & 5.000 \\
\hline Board Size & 9.713 & 2.212 & 8.000 & 10.000 & 11.000 \\
\hline LogAsset & 7.723 & 1.966 & 6.555 & 7.876 & 9.134 \\
\hline Analyst Following & 9.216 & 8.396 & 1.000 & 7.000 & 15.000 \\
\hline InstOwn & 0.641 & 0.332 & 0.480 & 0.750 & 0.886 \\
\hline$M t o B$ & 1.825 & 1.165 & 1.168 & 1.498 & 2.080 \\
\hline OCF Volatility & 0.052 & 0.092 & 0.020 & 0.033 & 0.056 \\
\hline Sales Volatility & 0.148 & 0.151 & 0.056 & 0.102 & 0.183 \\
\hline Invest Volatility & 5.564 & 6.076 & 1.905 & 3.769 & 7.166 \\
\hline Tangible & 0.289 & 0.235 & 0.103 & 0.216 & 0.436 \\
\hline$K$-structure & 0.209 & 0.200 & 0.051 & 0.159 & 0.298 \\
\hline OCF to Sale & -0.042 & 2.439 & 0.047 & 0.100 & 0.173 \\
\hline div_payer & 0.596 & 0.491 & 0.000 & 1.000 & 1.000 \\
\hline FirmAge & 29.249 & 21.607 & 13.000 & 23.000 & 41.000 \\
\hline OprCycle & 4.527 & 0.747 & 4.136 & 4.616 & 4.996 \\
\hline Loss & 0.204 & 0.403 & 0.000 & 0.000 & 0.000 \\
\hline
\end{tabular}

Panel B. Test of differences in investment efficiency

\begin{tabular}{|c|c|c|c|c|c|c|c|c|c|c|}
\hline & & \multicolumn{2}{|c|}{ None } & \multicolumn{2}{|c|}{ Temporary } & \multicolumn{2}{|c|}{ Permanent } & \multirow{2}{*}{$\begin{array}{c}\text { (4) } \\
\text { None vs. } \\
\text { Temporary } \\
\text { t-stat }\end{array}$} & \multirow{2}{*}{$\begin{array}{c}(5) \\
\text { None vs. } \\
\text { Permanent } \\
\text { t-stat } \\
\end{array}$} & \multirow{2}{*}{$\begin{array}{c}(6) \\
\begin{array}{c}\text { Temporary vs } \\
\text { Permanent }\end{array} \\
\text { t-stat } \\
\end{array}$} \\
\hline & & $\mathrm{N}$ & Mean & $\mathrm{N}$ & Mean & $\mathrm{N}$ & Mean & & & \\
\hline \multirow{3}{*}{$\begin{array}{l}\text { Investment } \\
\text { inefficiency } \\
\text { (Indicator) }\end{array}$} & over- or under-investment & 2,922 & 0.495 & 473 & 0.507 & 2,378 & 0.484 & $(0.49)$ & $(-0.81)$ & $(-0.93)$ \\
\hline & over-investment & 867 & 0.446 & 151 & 0.543 & 749 & 0.435 & $(2.20)^{*}$ & $(-0.45)$ & $(-2.42)^{*}$ \\
\hline & under-investment & 2,055 & 0.516 & 322 & 0.491 & 1,629 & 0.506 & $(-0.84)$ & $(-0.56)$ & $(0.52)$ \\
\hline \multirow{2}{*}{$\begin{array}{l}\text { Investment } \\
\text { inefficiency } \\
\text { (Continuous) }\end{array}$} & over- or under-investment & 2,922 & 6.663 & 473 & 7.493 & 2,378 & 6.460 & $(2.11)^{*}$ & $(-1.08)$ & $(-2.60) * *$ \\
\hline & under-investment & 2,055 & 6.534 & 322 & 6.651 & 1,629 & 6.073 & $(0.35)$ & $(-2.69) * *$ & $(-1.71)$ \\
\hline
\end{tabular}




\begin{tabular}{clrrrrrrrrrr}
\hline Change in & over- or under-investment & 2,487 & 0.099 & 449 & -0.085 & 1,995 & -0.073 & $(-0.44)$ & $(-0.87)$ & $(0.03)$ & $(03)$ \\
Investment & over-investment & 761 & -0.876 & 148 & -1.266 & 628 & -0.740 & $(-0.36)$ & $(0.27)$ & $(0.48)$ & $(-0)$ \\
inefficiency & under-investment & 1,726 & 0.529 & 301 & 0.495 & 1,367 & 0.233 & $(-0.10)$ & $(-1.65)$ & $(-0.76)$ & 0
\end{tabular}

This table reports average values of investment inefficiency variables for different groups, and differences among the pairs. We use three types of investment inefficiency measures. Continuous measure is the absolute value of the residuals from a regression of a firm's investment on sales growth. Indicator variable is equal to one if the absolute residual is above median. Change variable takes the difference in residuals of the current and following year. Observations with positive (negative) residuals are classified as overinvestment (underinvestment).

Panel C. Effects of finance committees on investment efficiency

\begin{tabular}{|c|c|c|c|c|c|c|c|c|c|c|}
\hline \multirow[b]{2}{*}{ VARIABLES } & \multirow[b]{2}{*}{$\begin{array}{c}\text { Pr. } \\
\text { Sign } \\
\end{array}$} & \multicolumn{3}{|c|}{ Over- or underinvestment } & \multicolumn{3}{|c|}{ Under-investment } & \multicolumn{3}{|c|}{ Over-investment } \\
\hline & & $\begin{array}{c}(1) \\
\text { Indicator } \\
\end{array}$ & $\begin{array}{c}(2) \\
\text { Continuous } \\
\end{array}$ & $\begin{array}{c}(3) \\
\text { Change } \\
\end{array}$ & $\begin{array}{c}(4) \\
\text { Indicator } \\
\end{array}$ & $\begin{array}{c}(5) \\
\text { Continuous } \\
\end{array}$ & $\begin{array}{c}(6) \\
\text { Change } \\
\end{array}$ & $\begin{array}{c}(7) \\
\text { Indicator } \\
\end{array}$ & $\begin{array}{c}(8) \\
\text { Continuous } \\
\end{array}$ & $\begin{array}{c}(9) \\
\text { Change } \\
\end{array}$ \\
\hline $\begin{array}{l}\text { Permanent } \\
\text { Finance Committee } \\
\text { Temporary } \\
\text { Finance Committee }\end{array}$ & - & $\begin{array}{c}0.117 \\
(1.20) \\
-0.266^{*} \\
(-1.69)\end{array}$ & $\begin{array}{l}0.200 \\
(0.67) \\
-0.365 \\
(-0.79)\end{array}$ & $\begin{array}{l}-0.227 \\
(-1.27) \\
-0.150 \\
(-0.52)\end{array}$ & $\begin{array}{c}-0.035 \\
(-0.28) \\
-0.420 * * \\
(-2.32)\end{array}$ & $\begin{array}{l}-0.051 \\
(-0.18) \\
-0.305 \\
(-0.70)\end{array}$ & $\begin{array}{c}-0.213 \\
(-1.19) \\
0.005 \\
(0.02)\end{array}$ & $\begin{array}{l}0.103 \\
(0.71) \\
0.186 \\
(0.77)\end{array}$ & $\begin{array}{l}0.839 \\
(1.34) \\
0.510 \\
(0.57)\end{array}$ & $\begin{array}{c}-0.852 \\
(-1.54) \\
-2.255^{* *} \\
(-2.41)\end{array}$ \\
\hline NCommittees & $?$ & $\begin{array}{c}-0.080 * \\
(-1.77)\end{array}$ & $\begin{array}{l}-0.176 \\
(-1.43)\end{array}$ & $\begin{array}{l}0.051 \\
(0.57)\end{array}$ & $\begin{array}{l}0.087 \\
(1.53)\end{array}$ & $\begin{array}{l}-0.071 \\
(-0.56)\end{array}$ & $\begin{array}{l}-0.074 \\
(-0.91)\end{array}$ & $\begin{array}{c}-0.157 * * \\
(-2.25)\end{array}$ & $\begin{array}{c}-0.550 * * \\
(-2.26)\end{array}$ & $\begin{array}{l}0.412 \\
(1.54)\end{array}$ \\
\hline Board Size & $?$ & $\begin{array}{l}-0.011 \\
(-0.46)\end{array}$ & $\begin{array}{l}0.035 \\
(0.54)\end{array}$ & $\begin{array}{l}0.035 \\
(0.74)\end{array}$ & $\begin{array}{c}-0.067 * * \\
(-2.32)\end{array}$ & $\begin{array}{l}0.009 \\
(0.13)\end{array}$ & $\begin{array}{l}0.052 \\
(1.06)\end{array}$ & $\begin{array}{c}-0.057^{*} \\
(-1.76)\end{array}$ & $\begin{array}{l}0.054 \\
(0.38)\end{array}$ & $\begin{array}{l}-0.029 \\
(-0.22)\end{array}$ \\
\hline Analyst Following & - & $\begin{array}{l}-0.008 \\
(-1.27)\end{array}$ & $\begin{array}{l}-0.026 \\
(-1.45)\end{array}$ & $\begin{array}{l}0.008 \\
(0.64)\end{array}$ & $\begin{array}{l}0.001 \\
(0.07)\end{array}$ & $\begin{array}{l}-0.025 \\
(-1.40)\end{array}$ & $\begin{array}{l}0.002 \\
(0.17)\end{array}$ & $\begin{array}{c}-0.016^{*} \\
(-1.74)\end{array}$ & $\begin{array}{l}-0.011 \\
(-0.31)\end{array}$ & $\begin{array}{l}0.013 \\
(0.33)\end{array}$ \\
\hline InstOwn & - & $\begin{array}{l}-0.188 \\
(-1.40)\end{array}$ & $\begin{array}{l}-0.549 \\
(-1.12)\end{array}$ & $\begin{array}{l}-0.194 \\
(-0.66)\end{array}$ & $\begin{array}{c}-0.387 * * \\
(-2.31)\end{array}$ & $\begin{array}{c}-0.946 * * \\
(-2.39)\end{array}$ & $\begin{array}{l}0.273 \\
(0.95)\end{array}$ & $\begin{array}{l}-0.004 \\
(-0.02)\end{array}$ & $\begin{array}{l}0.089 \\
(0.08)\end{array}$ & $\begin{array}{l}-1.221 \\
(-1.39)\end{array}$ \\
\hline$M t o B$ & + & $\begin{array}{c}-0.069 * \\
(-1.88)\end{array}$ & $\begin{array}{l}0.130 \\
(0.87)\end{array}$ & $\begin{array}{l}-0.153 \\
(-0.97)\end{array}$ & $\begin{array}{l}-0.068 \\
(-1.32)\end{array}$ & $\begin{array}{l}-0.178 \\
(-1.30)\end{array}$ & $\begin{array}{l}0.213 \\
(1.62)\end{array}$ & $\begin{array}{c}0.089 * \\
(1.72)\end{array}$ & $\begin{array}{l}0.320 \\
(1.15)\end{array}$ & $\begin{array}{l}-0.517 \\
(-1.64)\end{array}$ \\
\hline OCF Volatility & + & $\begin{array}{l}0.049 \\
(0.09)\end{array}$ & $\begin{array}{l}3.186 \\
(0.88)\end{array}$ & $\begin{array}{l}-1.289 \\
(-0.52)\end{array}$ & $\begin{array}{l}0.651 \\
(0.83)\end{array}$ & $\begin{array}{l}-0.176 \\
(-0.16)\end{array}$ & $\begin{array}{l}-1.718 \\
(-0.74)\end{array}$ & $\begin{array}{l}-0.341 \\
(-0.32)\end{array}$ & $\begin{array}{l}3.939 \\
(0.46)\end{array}$ & $\begin{array}{l}-0.568 \\
(-0.11)\end{array}$ \\
\hline Sales Volatility & + & $\begin{array}{l}0.292 \\
(1.13)\end{array}$ & $\begin{array}{l}0.309 \\
(0.40)\end{array}$ & $\begin{array}{l}0.749 \\
(0.97)\end{array}$ & $\begin{array}{l}-0.282 \\
(-0.92)\end{array}$ & $\begin{array}{c}1.501 * * \\
(2.43)\end{array}$ & $\begin{array}{l}-0.334 \\
(-0.53)\end{array}$ & $\begin{array}{l}-0.252 \\
(-0.59)\end{array}$ & $\begin{array}{l}-1.398 \\
(-0.65)\end{array}$ & $\begin{array}{l}3.497 \\
(1.48)\end{array}$ \\
\hline Invest Volatility & + & $\begin{array}{c}0.023 * * * \\
(3.07)\end{array}$ & $\begin{array}{c}0.125 * * * \\
(3.95)\end{array}$ & $\begin{array}{l}-0.031 \\
(-1.39)\end{array}$ & $\begin{array}{c}0.036 * * * \\
(3.89)\end{array}$ & $\begin{array}{l}0.036 \\
(1.57)\end{array}$ & $\begin{array}{l}-0.001 \\
(-0.03)\end{array}$ & $\begin{array}{c}0.055^{* * * *} \\
(4.60)\end{array}$ & $\begin{array}{c}0.243 * * * \\
(3.08)\end{array}$ & $\begin{array}{l}-0.070 \\
(-1.00)\end{array}$ \\
\hline Tangible & - & $\begin{array}{c}-1.784 * * * \\
(-7.26)\end{array}$ & $\begin{array}{c}-3.688 * * * \\
(-6.17)\end{array}$ & $\begin{array}{l}0.047 \\
(0.12)\end{array}$ & $\begin{array}{c}-2.113 * * * \\
(-7.75)\end{array}$ & $\begin{array}{c}-4.362 * * * \\
(-6.90)\end{array}$ & $\begin{array}{c}1.065 * * * \\
(2.65)\end{array}$ & $\begin{array}{l}-0.102 \\
(-0.36)\end{array}$ & $\begin{array}{c}-2.642 * \\
(-1.93)\end{array}$ & $\begin{array}{l}-0.868 \\
(-0.69)\end{array}$ \\
\hline$K$-structure & - & $\begin{array}{l}0.373 \\
(1.35)\end{array}$ & $\begin{array}{l}-1.079 \\
(-1.40)\end{array}$ & $\begin{array}{l}-0.145 \\
(-0.28)\end{array}$ & $\begin{array}{l}-0.219 \\
(-0.69)\end{array}$ & $\begin{array}{l}0.407 \\
(0.61)\end{array}$ & $\begin{array}{c}-0.829 * \\
(-1.78)\end{array}$ & $\begin{array}{c}-0.778^{*} \\
(-1.88)\end{array}$ & $\begin{array}{c}-2.805^{*} \\
(-1.67)\end{array}$ & $\begin{array}{l}0.647 \\
(0.39)\end{array}$ \\
\hline OCF to Sale & - & -0.019 & -0.087 & 0.020 & 0.016 & -0.024 & 0.079 & $-0.274 * * *$ & -0.040 & -0.075 \\
\hline
\end{tabular}




\begin{tabular}{|c|c|c|c|c|c|c|c|c|c|c|}
\hline & & $(-0.97)$ & $(-0.93)$ & $(0.14)$ & $(0.95)$ & $(-0.43)$ & $(1.62)$ & $(-2.72)$ & $(-0.30)$ & $(-0.31)$ \\
\hline \multirow[t]{2}{*}{ FinancialSlack } & + & -0.002 & 0.012 & 0.015 & 0.010 & 0.011 & 0.016 & 0.006 & 0.026 & 0.011 \\
\hline & & $(-0.62)$ & $(0.73)$ & $(0.85)$ & (1.19) & $(0.63)$ & $(1.27)$ & $(0.55)$ & $(0.47)$ & $(0.21)$ \\
\hline \multirow[t]{2}{*}{ div_payer } & - & 0.096 & 0.235 & 0.007 & $-0.236 * *$ & 0.405 & 0.061 & -0.082 & 0.634 & -0.797 \\
\hline & & $(0.99)$ & $(0.93)$ & $(0.04)$ & $(-2.09)$ & (1.49) & $(0.32)$ & $(-0.63)$ & (1.29) & $(-1.38)$ \\
\hline \multirow[t]{2}{*}{ LogAsset } & - & -0.054 & -0.091 & -0.053 & 0.033 & 0.140 & $-0.184 * *$ & -0.013 & $-0.827 * * *$ & 0.365 \\
\hline & & $(-1.53)$ & $(-0.90)$ & $(-0.69)$ & $(0.75)$ & $(1.45)$ & $(-2.57)$ & $(-0.27)$ & $(-3.30)$ & $(1.48)$ \\
\hline \multirow[t]{2}{*}{ FirmAge } & - & 0.002 & 0.006 & -0.004 & -0.001 & 0.005 & -0.004 & 0.002 & 0.007 & -0.005 \\
\hline & & $(0.89)$ & $(1.05)$ & $(-1.20)$ & $(-0.19)$ & (1.02) & $(-1.09)$ & $(0.64)$ & $(0.65)$ & $(-0.51)$ \\
\hline \multirow[t]{2}{*}{ OprCycle } & + & -0.071 & 0.032 & 0.019 & 0.083 & $0.644 * * *$ & 0.004 & -0.086 & $-0.961 * *$ & -0.186 \\
\hline & & $(-1.04)$ & $(0.15)$ & $(0.13)$ & (1.02) & (2.91) & $(0.03)$ & $(-1.04)$ & $(-2.41)$ & $(-0.43)$ \\
\hline \multirow[t]{2}{*}{ Loss } & + & 0.048 & $0.691 * *$ & -0.149 & 0.158 & -0.106 & 0.044 & 0.238 & $2.323 * * *$ & -0.573 \\
\hline & & $(0.51)$ & (2.32) & $(-0.55)$ & $(1.50)$ & $(-0.44)$ & $(0.21)$ & (1.47) & (3.34) & $(-0.73)$ \\
\hline \multirow[t]{2}{*}{ Constant } & & $1.012 * *$ & $6.002 * * *$ & -0.114 & 0.642 & 0.706 & $2.750 * *$ & $1.230 * *$ & $18.238 * * *$ & -5.027 \\
\hline & & $(2.00)$ & (3.76) & $(-0.10)$ & (1.14) & $(0.44)$ & $(2.51)$ & (2.06) & $(6.31)$ & $(-1.65)$ \\
\hline \multirow{6}{*}{$\begin{array}{l}\text { Observations } \\
\text { Pseudo R2 } \\
\text { R-squared } \\
\text { Adj-R2 } \\
\text { Fixed Effects }\end{array}$} & & 5,773 & 5,773 & 4,931 & 4,006 & 4,006 & 3,394 & 1,767 & 1,767 & 1,537 \\
\hline & & 0.125 & & & 0.0666 & & & 0.0664 & & \\
\hline & & & 0.220 & 0.013 & & 0.381 & 0.031 & & 0.211 & 0.043 \\
\hline & & & 0.215 & 0.00525 & & 0.374 & 0.0196 & & 0.193 & 0.0185 \\
\hline & & Year \& & Year \& & Year \& & Year \& & Year \& & Year \& & Year \& & Year \& & Year \& \\
\hline & & Industry & Industry & Industry & Industry & Industry & Industry & Industry & Industry & Industry \\
\hline
\end{tabular}

This panel reports logit and OLS regression estimates of equation (4). We estimate over- and under-investment combined in columns (1) through (3), only for underinvestment in columns (4) through (6), and only for over-investment in columns (7) through (9). Dependent variable in columns (1), (4), (7) is an indicator which equals one if absolute value of residual is above median. Dependent variable in columns (2), (5), (8) is absolute value of residual. Dependent variable in columns (3), (6), (8) is change in absolute value of residual. The numbers in parentheses are robust z-statistics and standard errors are clustered by firm. *, **, *** indicate significance at the $10 \%, 5 \%$, and $1 \%$ level respectively, in two-tailed tests. Industry fixed effects are classified using Fama and French 12 sectors. All other variables are defined in Appendix C. 


\section{Table5}

Analysis of finance committee and capex guidance

Panel A. Descriptive statistics for variables in our regression analyses of capex guidance $(\mathrm{N}=4,394)$

\begin{tabular}{|c|c|c|c|c|c|}
\hline & Mean & Std & Q1 & Median & Q3 \\
\hline Permanent Finance Committee & 0.455 & 0.498 & 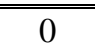 & 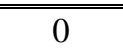 & 1 \\
\hline Temporary Finance Committee & 0.049 & 0.215 & 0 & 0 & 0 \\
\hline NCommittees & 4.337 & 1.051 & 4.000 & 4.000 & 5.000 \\
\hline Board Size & 10.254 & 1.931 & 9.000 & 10.000 & 12.000 \\
\hline Analyst Dispersion & 0.046 & 0.061 & 0.010 & 0.030 & 0.050 \\
\hline Leverage & 0.468 & 0.858 & 0.113 & 0.238 & 0.459 \\
\hline Tobin $Q$ & 1.892 & 0.958 & 1.280 & 1.636 & 2.173 \\
\hline$R O A$ & 0.142 & 0.075 & 0.099 & 0.135 & 0.178 \\
\hline Loss & 0.122 & 0.328 & 0.000 & 0.000 & 0.000 \\
\hline LogAsset & 8.391 & 1.422 & 7.401 & 8.359 & 9.465 \\
\hline Ret Volatility & 0.091 & 0.053 & 0.056 & 0.078 & 0.110 \\
\hline Analyst Following & 12.557 & 7.212 & 7.000 & 11.000 & 18.000 \\
\hline InstOwn & 0.730 & 0.290 & 0.674 & 0.815 & 0.908 \\
\hline Tangible & 0.266 & 0.210 & 0.102 & 0.202 & 0.380 \\
\hline
\end{tabular}

Panel B. Test of differences in capex guidance quality

\begin{tabular}{|c|c|c|c|c|c|c|c|c|c|}
\hline & \multicolumn{2}{|c|}{ (1) } & \multicolumn{2}{|c|}{ (2) } & \multicolumn{2}{|c|}{ (3) } & \multirow{2}{*}{$\begin{array}{c}\text { (4) } \\
\text { None vs. } \\
\text { Temporary }\end{array}$} & \multirow{2}{*}{$\begin{array}{c}\text { (5) } \\
\text { None vs. } \\
\text { Permanent }\end{array}$} & \multirow{3}{*}{$\begin{array}{c}\text { (6) } \\
\begin{array}{c}\text { Temporary vs. } \\
\text { Permanent }\end{array} \\
\text { t-stat } \\
\end{array}$} \\
\hline & \multicolumn{2}{|c|}{ None } & \multicolumn{2}{|c|}{ Temporary } & \multicolumn{2}{|c|}{ Permanent } & & & \\
\hline & $\mathrm{N}$ & Mean & $\mathrm{N}$ & Mean & $\mathrm{N}$ & Mean & t-stat & t-stat & \\
\hline Capex Issuance & 2,179 & 0.767 & 214 & 0.724 & 2,001 & 0.784 & $(-1.35)$ & $(1.30)$ & $(1.87)$ \\
\hline Capex Nforecast & 1,733 & 3.630 & 157 & 3.834 & 1,577 & 3.770 & $(1.17)$ & $(1.86)$ & $(-0.36)$ \\
\hline Capex Forecast Error & 1,734 & 0.046 & 158 & 0.044 & 1,578 & 0.045 & $(-0.27)$ & $(-0.26)$ & $(0.13)$ \\
\hline Capex Forecast Range & 1,735 & 0.012 & 159 & 0.012 & 1,579 & 0.011 & $(0.00)$ & $(-0.76)$ & $(-0.31)$ \\
\hline Change in Nforecast & 1,643 & 0.323 & 146 & 0.664 & 1,503 & 0.301 & $(1.98)^{*}$ & $(-0.30)$ & $(-2.10)^{*}$ \\
\hline Change in Forecast Error & 1,394 & 0.003 & 111 & 0.000 & 1,292 & 0.000 & $(-0.55)$ & $(-1.36)$ & $(-0.05)$ \\
\hline Change in Forecast Range & 1,442 & 0.000 & 121 & 0.001 & 1,336 & 0.000 & $(0.27)$ & $(-0.10)$ & $(-0.31)$ \\
\hline
\end{tabular}

This panel reports average values of capex guidance quality and differences among the pairs. All variables are defined in Appendix C. 
Panel C. Effects of finance committees on capex guidance quality

\begin{tabular}{|c|c|c|c|c|c|c|c|c|}
\hline VARIABLES & Pr. Sign & $\begin{array}{c}\text { (1) } \\
\text { Capex } \\
\text { Issuance }\end{array}$ & $\begin{array}{c}\text { (2) } \\
\text { Capex } \\
\text { Nforecast }\end{array}$ & $\begin{array}{l}(3) \\
\text { Capex } \\
\text { Forecast } \\
\text { Error }\end{array}$ & $\begin{array}{c}(4) \\
\text { Capex } \\
\text { Forecast } \\
\text { Range }\end{array}$ & $\Delta N$ forecast & $\begin{array}{c}\text { (6) } \\
\Delta \text { Forecast } \\
\text { Error }\end{array}$ & $\begin{array}{c}\text { (7) } \\
\Delta \text { Forecast } \\
\text { Range }\end{array}$ \\
\hline Permanent Finance Committee & + & $\begin{array}{l}-0.023 \\
(-0.13)\end{array}$ & $\begin{array}{l}0.063 \\
(0.41)\end{array}$ & $\begin{array}{l}0.004 \\
(0.67)\end{array}$ & $\begin{array}{l}-0.000 \\
(-0.35)\end{array}$ & $\begin{array}{l}0.016 \\
(0.39)\end{array}$ & $\begin{array}{l}-0.003 \\
(-1.12)\end{array}$ & $\begin{array}{l}-0.000 \\
(-0.11)\end{array}$ \\
\hline Temporary Finance Committee & + & $\begin{array}{l}0.046 \\
(0.18) \\
\end{array}$ & $\begin{array}{c}0.517 * * \\
(2.07) \\
\end{array}$ & $\begin{array}{r}-0.009 \\
(-1.39) \\
\end{array}$ & $\begin{array}{r}-0.001 \\
(-0.63) \\
\end{array}$ & $\begin{array}{l}0.022 \\
(0.26) \\
\end{array}$ & $\begin{array}{l}-0.005 \\
(-1.20) \\
\end{array}$ & $\begin{array}{r}-0.001 \\
(-1.44) \\
\end{array}$ \\
\hline NCommittees & $?$ & $\begin{array}{l}0.033 \\
(0.40)\end{array}$ & $\begin{array}{c}0.014 \\
(0.18)\end{array}$ & $\begin{array}{l}-0.002 \\
(-0.83)\end{array}$ & $\begin{array}{l}0.000 \\
(0.86)\end{array}$ & $\begin{array}{l}-0.012 \\
(-0.55)\end{array}$ & $\begin{array}{l}0.000 \\
(0.06)\end{array}$ & $\begin{array}{l}0.000 \\
(1.46)\end{array}$ \\
\hline Board Size & $?$ & $\begin{array}{c}0.080 * * \\
(2.05)\end{array}$ & $\begin{array}{l}0.008 \\
(0.23)\end{array}$ & $\begin{array}{c}-0.002 * \\
(-1.75)\end{array}$ & $\begin{array}{l}-0.000 \\
(-0.05)\end{array}$ & $\begin{array}{l}-0.001 \\
(-0.05)\end{array}$ & $\begin{array}{l}-0.000 \\
(-0.60)\end{array}$ & $\begin{array}{l}-0.000 \\
(-0.21)\end{array}$ \\
\hline$R O A$ & + & $\begin{array}{l}0.232 \\
(0.23)\end{array}$ & $\begin{array}{c}-1.491 * \\
(-1.68)\end{array}$ & $\begin{array}{c}-0.088 * * * \\
(-2.60)\end{array}$ & $\begin{array}{l}-0.005 \\
(-0.61)\end{array}$ & $\begin{array}{l}-0.154 \\
(-0.31)\end{array}$ & $\begin{array}{l}0.036 \\
(1.20)\end{array}$ & $\begin{array}{c}0.009 * \\
(1.68)\end{array}$ \\
\hline Loss & - & $\begin{array}{l}0.242 \\
(1.24)\end{array}$ & $\begin{array}{c}-0.313 * * \\
(-2.03)\end{array}$ & $\begin{array}{l}0.001 \\
(0.12)\end{array}$ & $\begin{array}{c}-0.002 * \\
(-1.75)\end{array}$ & $\begin{array}{l}-0.055 \\
(-0.57)\end{array}$ & $\begin{array}{l}0.003 \\
(0.74)\end{array}$ & $\begin{array}{l}-0.001 \\
(-1.13)\end{array}$ \\
\hline LogAsset & + & $\begin{array}{c}-0.181 * * \\
(-2.24)\end{array}$ & $\begin{array}{c}0.155^{* *} \\
(2.02)\end{array}$ & $\begin{array}{c}-0.008 * * * \\
(-3.14)\end{array}$ & $\begin{array}{c}-0.003 * * * \\
(-5.17)\end{array}$ & $\begin{array}{l}0.001 \\
(0.06)\end{array}$ & $\begin{array}{l}-0.001 \\
(-0.75)\end{array}$ & $\begin{array}{l}-0.000 \\
(-0.24)\end{array}$ \\
\hline TobinQ & + & $\begin{array}{c}-0.144 * * \\
(-1.99)\end{array}$ & $\begin{array}{l}-0.059 \\
(-0.74)\end{array}$ & $\begin{array}{c}0.012 * * * \\
(3.53)\end{array}$ & $\begin{array}{c}0.002 * \\
(1.95)\end{array}$ & $\begin{array}{l}-0.001 \\
(-0.04)\end{array}$ & $\begin{array}{l}-0.001 \\
(-0.47)\end{array}$ & $\begin{array}{l}-0.000 \\
(-0.76)\end{array}$ \\
\hline Leverage & + & $\begin{array}{l}0.068 \\
(0.64)\end{array}$ & $\begin{array}{l}-0.004 \\
(-0.07)\end{array}$ & $\begin{array}{l}-0.003 \\
(-1.39)\end{array}$ & $\begin{array}{l}-0.001 \\
(-1.61)\end{array}$ & $\begin{array}{l}0.057 \\
(1.63)\end{array}$ & $\begin{array}{l}0.000 \\
(0.18)\end{array}$ & $\begin{array}{l}0.000 \\
(0.14)\end{array}$ \\
\hline Ret Volatility & - & $\begin{array}{l}-0.389 \\
(-0.27)\end{array}$ & $\begin{array}{l}0.712 \\
(0.67)\end{array}$ & $\begin{array}{c}0.072 * \\
(1.96)\end{array}$ & $\begin{array}{l}0.003 \\
(0.27)\end{array}$ & $\begin{array}{l}-0.419 \\
(-0.71)\end{array}$ & $\begin{array}{l}-0.047 \\
(-1.46)\end{array}$ & $\begin{array}{l}-0.000 \\
(-0.01)\end{array}$ \\
\hline Analyst Dispersion & - & $\begin{array}{c}3.557 * * * \\
(2.99)\end{array}$ & $\begin{array}{c}-1.588 * * \\
(-1.97)\end{array}$ & $\begin{array}{c}0.070 * * \\
(2.37)\end{array}$ & $\begin{array}{c}0.014 * * \\
(2.36)\end{array}$ & $\begin{array}{l}-0.069 \\
(-0.17)\end{array}$ & $\begin{array}{l}0.008 \\
(0.41)\end{array}$ & $\begin{array}{c}-0.007 * \\
(-1.95)\end{array}$ \\
\hline Analyst Following & + & $\begin{array}{l}0.012 \\
(0.89)\end{array}$ & $\begin{array}{c}0.025^{*} \\
(1.74)\end{array}$ & $\begin{array}{l}-0.000 \\
(-0.11)\end{array}$ & $\begin{array}{l}-0.000 \\
(-0.42)\end{array}$ & $\begin{array}{l}0.000 \\
(0.11)\end{array}$ & $\begin{array}{l}-0.000 \\
(-1.45)\end{array}$ & $\begin{array}{l}-0.000 \\
(-0.76)\end{array}$ \\
\hline InstOwn & + & $\begin{array}{l}0.476 \\
(1.30)\end{array}$ & $\begin{array}{l}0.264 \\
(0.68)\end{array}$ & $\begin{array}{l}0.004 \\
(0.34)\end{array}$ & $\begin{array}{l}0.000 \\
(0.01)\end{array}$ & $\begin{array}{l}-0.104 \\
(-0.81)\end{array}$ & $\begin{array}{l}-0.002 \\
(-0.28)\end{array}$ & $\begin{array}{l}0.002 \\
(1.05)\end{array}$ \\
\hline Tangible & + & $\begin{array}{c}3.969 * * * \\
(5.75)\end{array}$ & $\begin{array}{c}2.767 * * * \\
(7.86)\end{array}$ & $\begin{array}{c}-0.075^{* * *} \\
(-6.47)\end{array}$ & $\begin{array}{c}-0.021 * * * \\
(-7.26)\end{array}$ & $\begin{array}{c}0.372 * * * \\
(3.39)\end{array}$ & $\begin{array}{l}-0.002 \\
(-0.42)\end{array}$ & $\begin{array}{l}-0.001 \\
(-0.36)\end{array}$ \\
\hline Invest Volatility & - & 0.003 & 0.004 & $0.001 *$ & 0.000 & 0.007 & 0.000 & 0.000 \\
\hline
\end{tabular}




\begin{tabular}{|c|c|c|c|c|c|c|c|}
\hline & $(0.26)$ & $(0.35)$ & $(1.74)$ & $(0.34)$ & $(1.41)$ & $(0.38)$ & $(0.44)$ \\
\hline Constant & $\begin{array}{l}1.270^{*} \\
(1.86)\end{array}$ & $\begin{array}{l}0.220 \\
(0.32)\end{array}$ & $\begin{array}{c}0.108 * * * \\
(4.95)\end{array}$ & $\begin{array}{c}0.023 * * * \\
(4.03)\end{array}$ & $\begin{array}{l}-0.019 \\
(-0.07)\end{array}$ & $\begin{array}{l}0.016 \\
(0.79)\end{array}$ & $\begin{array}{c}-0.013 * * \\
(-1.99)\end{array}$ \\
\hline Observations & 4,394 & 3,629 & 3,467 & 3,628 & 4,542 & 2,797 & 3,002 \\
\hline Pseudo R2 & 0.169 & & & & & & \\
\hline R-squared & & 0.160 & 0.149 & 0.173 & 0.054 & 0.014 & 0.022 \\
\hline Adj-R2 & & 0.152 & 0.140 & 0.165 & 0.0462 & 0.00156 & 0.0105 \\
\hline Fixed Effects & Year \& & Year \& & Year \& & Year \& & Year \& & Year \& & Year \& \\
\hline & Industry & Industry & Industry & Industry & Industry & Industry & Industry \\
\hline
\end{tabular}


Table 6

\section{Additional analysis}

Panel A. Additional analyses of finance committees and investment efficiency

\begin{tabular}{|c|c|c|c|c|c|c|c|c|}
\hline & \multicolumn{4}{|c|}{ Dep. var=Investment Inefficiency (Indicator variable) } & \multicolumn{3}{|c|}{ Dep. var=Investment Inefficiency (Change variable) } & $\begin{array}{r}(8) \\
\text { riable) }\end{array}$ \\
\hline Permanent Investment Committee & $\begin{array}{c}0.081 \\
(0.83)\end{array}$ & & & & $\begin{array}{c}-0.375 * * \\
(-2.15)\end{array}$ & & & \\
\hline Temporary Investment Committee & $\begin{array}{c}-0.319 * * \\
(-2.01)\end{array}$ & & & & $\begin{array}{l}-0.457 \\
(-1.40)\end{array}$ & & & \\
\hline Finance Committee & & $\begin{array}{l}0.038 \\
(0.41)\end{array}$ & & & & $\begin{array}{l}-0.115 \\
(-0.65)\end{array}$ & & \\
\hline Finance Committee Adopt Year & & $\begin{array}{c}0.275^{*} \\
(1.71)\end{array}$ & & & & $\begin{array}{c}-1.356 * * \\
(-2.09)\end{array}$ & & \\
\hline Large Finance Committee & & & $\begin{array}{l}0.108 \\
(1.04)\end{array}$ & & & & $\begin{array}{l}-0.297 \\
(-1.35)\end{array}$ & \\
\hline Small Finance Committee & & & $\begin{array}{l}0.010 \\
(0.10)\end{array}$ & & & & $\begin{array}{l}-0.136 \\
(-0.66)\end{array}$ & \\
\hline Strong Finance Committee & & & & $\begin{array}{l}0.051 \\
(0.47)\end{array}$ & & & & $\begin{array}{l}-0.303 \\
(-1.41)\end{array}$ \\
\hline Weak Finance Committee & & & & $\begin{array}{l}0.063 \\
(0.60)\end{array}$ & & & & $\begin{array}{l}-0.127 \\
(-0.67)\end{array}$ \\
\hline Observations & 5,773 & 5,773 & 5,773 & 5,773 & 4,931 & 4,931 & 4,931 & 4,931 \\
\hline Pseudo R2 & 0.125 & 0.124 & 0.124 & 0.123 & & & & \\
\hline R-squared & & & & & 0.014 & 0.014 & 0.013 & 0.013 \\
\hline Adj-R2 & & & & & 0.00566 & 0.00660 & 0.00531 & 0.00532 \\
\hline Fixed Effects & $\begin{array}{l}\text { Year \& } \\
\text { Industry }\end{array}$ & $\begin{array}{c}\text { Year \& } \\
\text { Industry }\end{array}$ & $\begin{array}{l}\text { Year \& } \\
\text { Industry }\end{array}$ & $\begin{array}{l}\text { Year \& } \\
\text { Industry }\end{array}$ & $\begin{array}{c}\text { Year \& } \\
\text { Industry }\end{array}$ & $\begin{array}{c}\text { Year \& } \\
\text { Industry }\end{array}$ & $\begin{array}{l}\text { Year \& } \\
\text { Industry }\end{array}$ & $\begin{array}{l}\text { Year \& } \\
\text { Industr }\end{array}$ \\
\hline Controls & Yes & Yes & Yes & Yes & Yes & Yes & Yes & Yes \\
\hline
\end{tabular}

This panel presents logit and OLS regression estimates of regressing investment inefficiency on a finance committee. The same control variables from Table 4 are included in the model but not tabulated for brevity. The numbers in parentheses are robust z-statistics and standard errors are clustered by firm. *,**, *** indicate significance at the $10 \%, 5 \%$, and $1 \%$ level respectively, in two-tailed tests. Industry fixed effects are classified using Fama and French 12 sectors. All other variables are defined in Appendix C. 
Panel B. Additional analyses of finance committees and capex guidance

\begin{tabular}{|c|c|c|c|c|c|c|c|c|}
\hline & (1) & & (3) & (4) & (5) & $(6)$ & (7) & (8) \\
\hline & \multicolumn{4}{|c|}{ Dep. Var= Capex forecast error } & \multicolumn{4}{|c|}{ Dep. Var $=\Delta$ Capex forecast error } \\
\hline Permanent Investment Committee & $\begin{array}{l}0.001 \\
(0.14)\end{array}$ & & & & $\begin{array}{l}-0.002 \\
(-0.90)\end{array}$ & & & \\
\hline Temporary Investment Committee & $\begin{array}{c}-0.014 * * \\
(-2.40)\end{array}$ & & & & $\begin{array}{c}-0.007 * \\
(-1.83)\end{array}$ & & & \\
\hline Finance Committee & & $\begin{array}{l}0.002 \\
(0.37)\end{array}$ & & & & $\begin{array}{l}-0.003 \\
(-1.22)\end{array}$ & & \\
\hline Finance Committee Adopt Year & & $\begin{array}{l}0.010 \\
(0.90)\end{array}$ & & & & $\begin{array}{l}-0.001 \\
(-0.05)\end{array}$ & & \\
\hline Large Finance Committee & & & $\begin{array}{l}-0.000 \\
(-0.03)\end{array}$ & & & & $\begin{array}{l}-0.003 \\
(-0.96)\end{array}$ & \\
\hline Small Finance Committee & & & $\begin{array}{l}0.005 \\
(0.81)\end{array}$ & & & & $\begin{array}{l}-0.003 \\
(-1.09)\end{array}$ & \\
\hline Strong Finance Committee & & & & $\begin{array}{l}-0.001 \\
(-0.24)\end{array}$ & & & & $\begin{array}{c}-0.004 * \\
(-1.69)\end{array}$ \\
\hline Weak Finance Committee & & & & $\begin{array}{l}0.006 \\
(0.84)\end{array}$ & & & & $\begin{array}{l}-0.001 \\
(-0.46)\end{array}$ \\
\hline Observations & 3,467 & 3,467 & 3,467 & 3,467 & 2,797 & 2,797 & 2,797 & 2,797 \\
\hline R-squared & 0.149 & 0.148 & 0.148 & 0.149 & 0.014 & 0.014 & 0.014 & 0.014 \\
\hline Adj-R2 & 0.140 & 0.140 & 0.140 & 0.140 & 0.00164 & 0.00150 & 0.00151 & 0.00180 \\
\hline $\begin{array}{l}\text { Fixed Effects } \\
\text { Controls }\end{array}$ & $\begin{array}{c}\text { Year \& } \\
\text { Industry } \\
\text { Yes }\end{array}$ & $\begin{array}{c}\text { Year \& } \\
\text { Industry } \\
\text { Yes }\end{array}$ & $\begin{array}{c}\text { Year \& } \\
\text { Industry } \\
\text { Yes }\end{array}$ & $\begin{array}{c}\text { Year \& } \\
\text { Industry } \\
\text { Yes }\end{array}$ & $\begin{array}{c}\text { Year \& } \\
\text { Industry } \\
\text { Yes }\end{array}$ & $\begin{array}{c}\text { Year \& } \\
\text { Industry } \\
\text { Yes }\end{array}$ & $\begin{array}{c}\text { Year \& } \\
\text { Industry } \\
\text { Yes }\end{array}$ & $\begin{array}{c}\text { Year \& } \\
\text { Industry } \\
\text { Yes }\end{array}$ \\
\hline
\end{tabular}

This panel presents OLS regression estimates of regressing capex forecast error on a finance committee. The same control variables from Table 5 are included in the model but not tabulated for brevity. The numbers in parentheses are robust $\mathrm{z}$-statistics and standard errors are clustered by firm. *,**, *** indicate significance at the $10 \%, 5 \%$, and $1 \%$ level respectively, in two-tailed tests. Industry fixed effects are classified using Fama and French 12 sectors. All other variables are defined in Appendix C. 